Espacio, Tiempo y Forma, Serie II, Historia Antigua, t. 23, 2010, págs. 145-175

\title{
La presencia de la música en los contextos funerarios griegos y etruscos
}

\author{
Music in Greek and Etruscan funerary context
}

\author{
MARÍA ISABEL RODRÍGUEZ LÓPEZ*
}

\begin{abstract}
RESUMEN
La relación entre la música y el más allá fue muy estrecha en el ámbito de las culturas de la Antigüedad Clásica, hecho que se pone de manifiesto tanto a través de la iconografía como en el registro arqueológico y en las fuentes escritas. Las ceremonias y los rituales luctuosos estuvieron frecuentemente acompañados por la música y las danzas. Se reforzaba, así, el sentido del duelo y se incrementaban, sin duda, los acentos dramáticos presentes en los ritos funerarios. En este trabajo se hace una reflexión acerca de los vínculos existentes entre la música y el mundo de la muerte en

Grecia y Etruria, desde una perspectiva amplia en la que la iconografía se entiende como reflejo de un conjunto de factores socioculturales que engloba mitos, creencias, costumbres y otros aspectos relacionados con la muerte. Por otra parte, la presencia de la música o los artefactos de naturaleza musical hallados en contextos funerarios permiten vislumbrar orientaciones del mayor interés en el marco de la sociedad: formas de vida, creencias y ritos funerarios, así como el papel de la música en el tránsito al más allá.
\end{abstract}

\begin{abstract}
The relationship between music and the beyond was very close in the cultures of Classical Antiquity, which is evident both in the iconography and in the archaeological records and in the written sources. The ceremonies and funeral rituals were frequently accompanied by music and dances. This way the feeling of grief was reinforced and undoubtedly the dramatic accents on the funeral rites were increased. In this article a reflection of the links between music and the world of death in Greece and Etruria is made, from a wide perspective in which the iconography is meant to reflect a set of socio-cultural factors that includes myths, beliefs, customs and other aspects related to the death. On the other hand, the presence of music and artifacts of a musical nature found in burial contexts enable to foresee very interesting aspect in the social framework: forms of life, beliefs and funerary rites, as well as the role of music in the journey to the beyond.
\end{abstract}

* U.C.M. E-mail: mirodrig@ghis.ucm.es. Esta investigación se ha llevado a cabo en el marco del proyecto I+D+I HAR2009-10029 «Iconografía Musical» UCM. 
PALABRAS CLAVE:

Iconografía Clásica, Iconografía Musical, Mundo funerario, Arqueología Clásica.
KEYWORDS:

Classic Iconography, Musical Iconography, Funerary World, Classic Archaeology.

\section{ANTECEDENTES}

En el registro arqueológico de las grandes civilizaciones clásicas, la música tuvo un papel muy destacado en relación con el mundo de la muerte. Así se pone de manifiesto tanto en los mitos musicales, de fuerte carga simbólica, como en los usos cotidianos de la música. Los hallazgos arqueológicos confirman que los vínculos entre la música y el más allá tienen un origen muy antiguo; ya en el mundo prehelénico, tanto en las Cícladas como en la cultura minoica, los objetos de naturaleza musical confirman esta cuestión; por otra parte, las obras artísticas con iconografía musical de estas culturas, nos permiten realizar una aproximación a dicho asunto.

Entre las numerosas estatuillas de mármol procedentes de las necrópolis cicládicas y difundidas hasta regiones tan alejadas como Cerdeña, destacan las que habitualmente se designan como ídolos. Estas obras representan, en su mayor parte, a figuras femeninas; sin embargo, cuando finalizaba el Cicládico Antiguo hicieron su aparición otras tipologías, entre las que destacan las esculturas de los conocidos músicos (figs. 1 y 2). En todos los casos, se trata de obras realizadas en alabastro o mármol de Paros que se caracterizan por su esquematización, sus perfiles redondeados y la falta de detalles. Este peculiar estilo artístico se debe, principalmente, a que el modelado se conseguía mediante el desgaste de la pieza con la piedra de esmeril o corindón (carbón cristalizado), un buen abrasivo cuyo principal centro de explotación era la isla de Naxos. La mayoría de estas figuras proceden de necrópolis, hecho que ha dado lugar a diversas interpretaciones en relación con el mundo funerario, siendo consideradas como Diosas de la muerte, que acompañan a los difuntos en el viaje hacia el más allá. También se ha señalado que pudieron ser amuletos con sentido apotropaico, especialmente las de menor tamaño, o indicadoras del lugar del enterramiento, a modo de estela. Algunas de estas figuras, sin embargo, han aparecido en distintas aldeas ${ }^{1}$. Sus orígenes no están claros, como tampoco lo está su evolución formal, aunque parece aceptarse, grosso modo, que surgirían en la última etapa del "Cicládico Antiguo l» como obras esquemáticas y que paulatinamente irían acrecentando la variedad de sus actitudes y la tendencia hacia un mayor naturalismo. A este estadio postrero pertenecen los músicos, una serie de figuras masculinas que representan a hombres tocando diversos instrumentos musicales y el bebedor de la colección Goulandris, esculturas más gruesas y rotundas en su volumetría que los ídolos femeninos, prácticamente planos.

1 Rodríguez López, M. I., «El arte cicládico», en E-Excellence. http://www.liceus.com, 2005. (21 pp.). ISBN: 84-9822-112-9. 


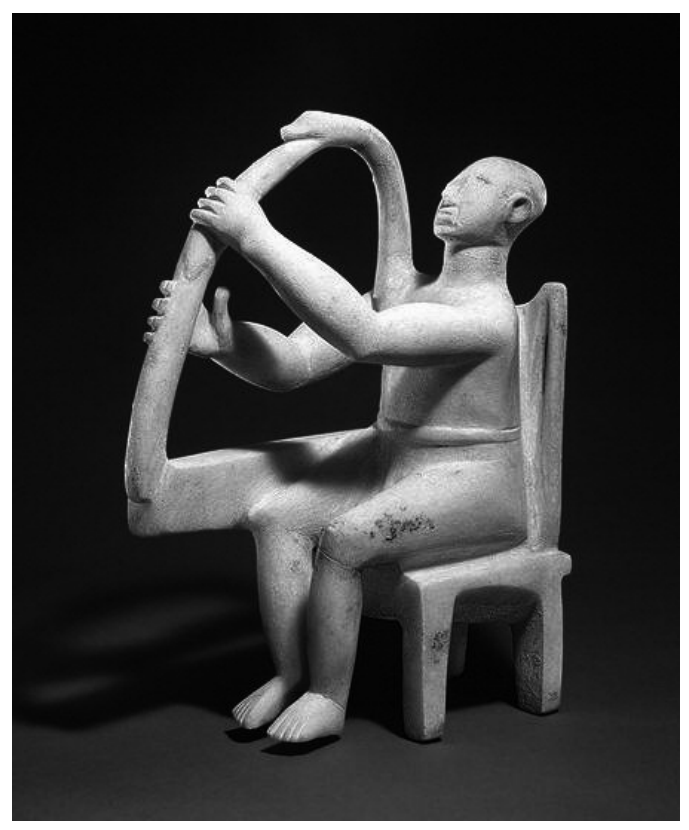

Fig. 1. Tañedor de arpa. Circa 2800-2700 a.C.; Cicládico temprano I-II. Mármol, Nueva York, Metropolitan Museum.

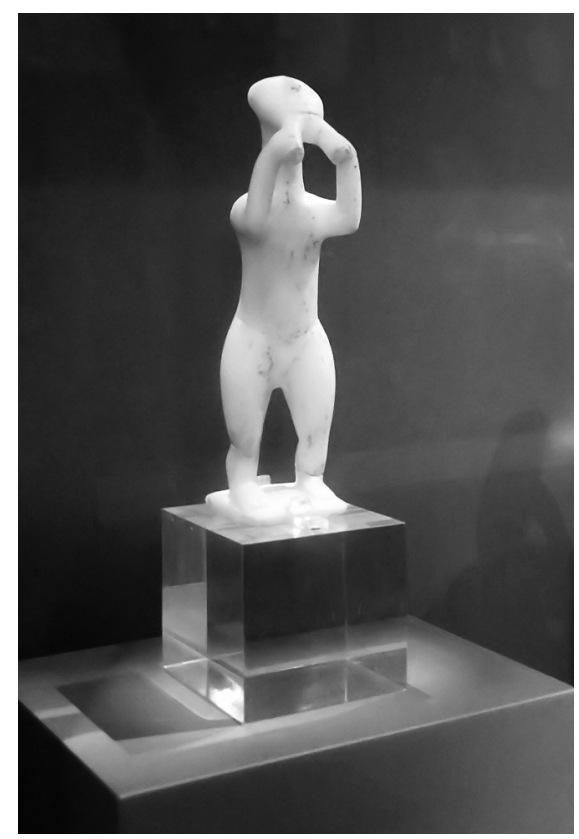

Fig. 2. Auletes procedente de Keros. Atenas, Museo Arqueológico Nacional 
Se conocen en la actualidad varios arpistas, tres tocadores de siringa, un auletes y un bebedor cuyo significado es un asunto de muy compleja interpretación. Resulta tentador, sin embargo, imaginar que los tañedores cicládicos fueran la petrificación de los intérpretes de threnoi (cantos fúnebres) y que sus melodías pudieran haber formado parte del ceremonial: la despedida del difunto con bebida ritual, los cantos fúnebres en su honor y el viaje al más allá (por el mar) en compañía de la Diosa Madre?

Aunque nos movemos en el terreno de las hipótesis, en el caso de los arpistas, la posición elevada de la cabeza sugiere un momento de fuerte espiritualidad y concentración ${ }^{3}$. La actitud de sus manos permite observar cómo el tañedor sostiene el instrumento y cómo el dedo pulgar de su diestra está todavía levantado, para expresar que acabara de pulsar una de las cuerdas del instrumento. Éste por su morfología parece de ascendencia oriental (Egipto, Mesopotamia).

Ya en el ámbito minoico, otro interesante ejemplo donde la iconografía funeraria nos permite atestiguar la presencia de la música en las ceremonias y ritos funerarios es el célebre Sarcófago de Hagia Triada 4 (Museo Arqueológico de Iraklion, Creta), que presenta una decoración pictórica con escenas de sacrificios y rituales funerarios acompañados por la música de la lira y del aulós. Se ha fechado en torno al 14501400 a.C., primer período de la dominación micénica en los más importantes centros cretenses, y en opinión de Burke, debe ser considerado como expresión de poder de las elites micénicas, quienes se sirvieron de imágenes minoicas para exhibir su ideología ${ }^{5}$. A diferencia de los característicos lárnaces de terracota, este sarcófagocista está realizado en piedra caliza, y su decoración presenta idéntica técnica (pintura al fresco sobre estuco) y análogos presupuestos estilísticos que las pinturas murales de los palacios ${ }^{6}$, hecho único en el arte funerario del Egeo.

Sobre uno de sus lados largos se ha representado una imagen sinóptica, con dos escenas simultáneas. En la izquierda, sobre un fondo blanco, se desarrolla una ceremonia ritual: una figura femenina, vestida con faldellín de piel de oveja, vierte un líquido en un gran caldero ${ }^{7}$, situado éste entre dos pilares coronados por hachas

2 Cfr. González Serrano, P., «Catábasis y Resurrección», Espacio, Tiempo y Forma, Serie II, t. 12, 1999, p.141.

${ }^{3}$ La iconografía griega de los siglos VI y V a.C. utilizó este procedimiento para representar el concepto de la inspiración divina, como puede verificarse en las representaciones de Orfeo, Dioniso y otros músicos que elevan su cabeza para conectar su pneuma, poder creador, con la divinidad misma.

${ }^{4}$ El sarcófago fue hallado en una tumba violada, en las proximidades del Palacio de Hagia Triada. Todo parece indicar que se tratara de una tumba principesca. Gracias a su iconografía, esta obra constituye una importantísima fuente de información sobre los ritos funerarios y es buen testimonio de la importancia que tuvo la mujer en la religión minoica.

5 Burke, B., «Materialization of Mycenaean Ideology and the Ayia Triadha Sarcophagus», American Journal of Archaeology, vol.109, n.3, 2005.

${ }^{6}$ El estilo de la decoración de los lárnaces de terracota estuvo, sin embargo, relacionado con la pintura cerámica, especialmente con el estilo llamado «denso».

7 Para Long, se trataría de vino y agua, mixtura destinada a las diosas simbolizadas mediante las dobles hachas coronadas por pájaros. El citado autor considera esta representación como una imagen de preparación del entierro. Cfr. Long, C., The Ayia Triadha Sarcophagus, A study of Late Minoan and Mycenaean Funerary Practices and Beliefs, Goteborg, 1974. 
dobles en las que están posados sendos pájaros; tras ella, otra mujer ataviada con elegante indumentaria y cuya cabeza está tocada con un sombrero adornado con plumas $^{8}$, porta sobre sus hombros dos grandes vasos o sítulas para libación; a continuación, una figura masculina acompaña el acto ritual con el sonido de de su lira, un instrumento cuya morfología primitiva remite al mundo oriental. Con su presencia, la música contribuye a sacralizar el acto ritual, a la dramatización del momento, que adquiriría, de este modo, gran solemnidad y empaque. En el centro, destacados sobre fondo azul, tres hombres vestidos con faldellines de piel de animal, se dirigen hacia la derecha, portando en sus manos dos animales y un modelo de barco respectivamente, ofrendas destinadas a la figura masculina (probablemente el difunto ${ }^{9}$ que está situada en el extremo derecho de la composición, junto a un edificio (¿la tumba?) y un árbol (¿el árbol de la vida?) (fig.3).

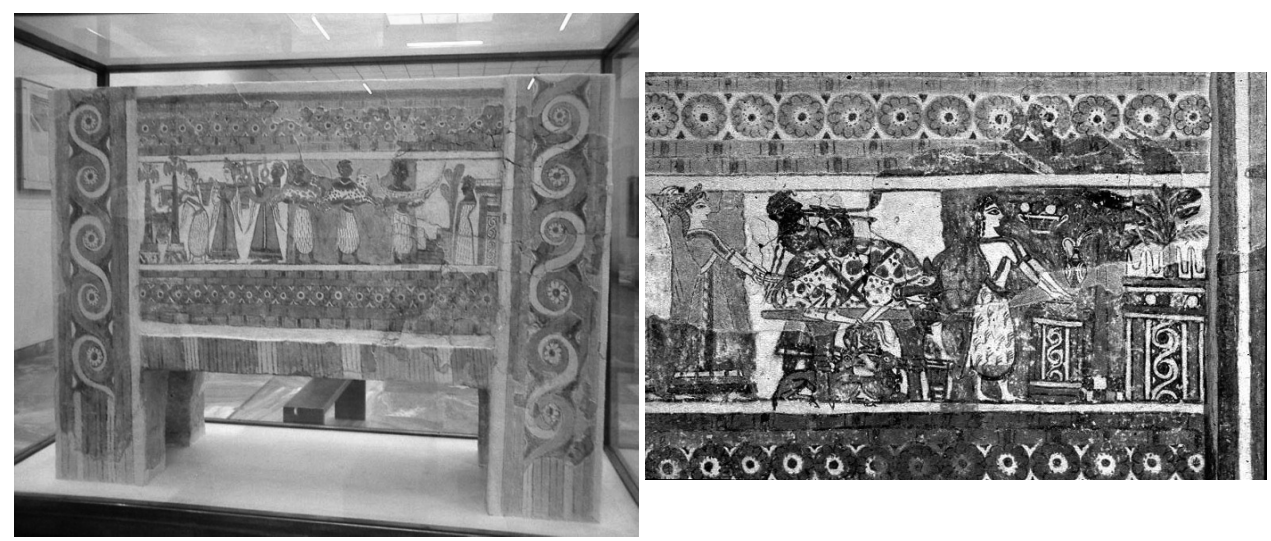

Figs. 3 y 4. Sarcófago de Hagia Triada. Circa 1400 a.C. Creta, Museo Arqueológico de Iraklion.

En el lado opuesto (fig.4) se representa una escena de sacrificio ritual. Una figura femenina vestida con faldellín ornado con motivos de crocus (flor de azafrán) realiza una libación ante un altar situado éste junto a una bipene coronada por un pájaro ${ }^{10}$. Junto a ella aparecen una canastilla flotante de frutas y una jarra. Otro altar coronado por cuernos de consagración y un árbol florido completan la escena. Tras esta figura femenina, sobre una mesa de ofrendas, la sangre de un toro maniatado y degollado se vierte sobre una sítula ${ }^{11}$.

8 Tocado semejante al que luce el llamado «Príncipe de los Lirios».

9 La interpretación de esta figura ha dado lugar a muchas hipótesis. Ha sido identificada como un sacerdote o como un dios, aunque la opinión más generalizada supone que se trata, por su rigidez e inmovilidad, de la figura del mismo difunto o de su espíritu, en actitud contemplar sus propias exequias.

10 La presencia del pájaro suele indicar la aparición o Epifanía de las diosas. Cfr. González Serrano, P., «Animales míticos en el mundo clásico», Espacio, Tiempo y Forma, Serie II, Historia Antigua, t. 11, 1998, p.143.

11 En relación con los juegos del toro y sus sacrificios véase Delgado Linacero, C., «Símbolo de poder y ofrenda religiosa. El toro en el Mediterráneo Antiguo», Historia 16, n.273, 1999, pp.76-85. 
Bajo la mesa, dos cabras salvajes están preparadas para el sacrificio. Tres mujeres que marchan en procesión completan la escena en el lado izquierdo, precedidas por el enérgico sonido de un aulós frigio, interpretado por un hombre joven. El instrumento posee cañas desiguales, una de ellas de pabellón abierto, lo que indica que estaría formado por cornamenta de animal. El músico-intérprete está situado junto a la mesa sacrificial, en el centro mismo de la composición, lo que sugiere, iconográficamente, que la música ocupara un lugar preeminente en el rito. Este instrumento de lengüeta fue considerado en la Antigüedad como instrumento de naturaleza orgiástica, unido, en la mayoría de los casos, a la purificación ritual, por lo que su presencia conviene, sin duda, al momento representado.

Los laterales del sarcófago están decorados con sendas parejas de figuras montadas sobre carros: uno de ellos muestra a dos figuras femeninas, probablemente dos diosas ${ }^{12}$ que conducen un carruaje tirado por animales alados, sobre cuyas alas se posa un pájaro. En el lateral opuesto, otra pareja (hombre y mujer ¿?) aparecen en un carro tirado por caballos acaso como expresión del tránsito del difunto al más allá ${ }^{13}$. Siguen siendo muchos los interrogantes para una correcta lectura e interpretación iconográfica de esta singular obra. Por nuestra parte, nos inclinamos a pensar, que todas las escenas pudieran haber formado un todo, un programa iconográfico coherente, que pone ante nuestros ojos lo que ya señalara en su día Martin P. Nilsson ${ }^{14}$, la unión de dos formas de culto (el funerario y el divino) a través de diferentes rituales y en conexión con las divinidades femeninas asociadas a ritos agrarios y a la muerte. La evidencia iconográfica prueba que la música sería parte esencial en el marco de dicho ritual.

\section{EL MUNDO GRIEGO}

Entre los temas musicales asociados a los contextos funerarios del mundo griego de época histórica destacan los mitos relacionados con Hermes, Apolo y las Musas, Aquiles, Orfeo, las sirenas, además del symposion y de diversas escenas de variada naturaleza representadas en los lecitoi de uso funerario que ofrecen testimonio de las costumbres y ritos asociados al culto de los muertos. Dicha conexión entre la música y la muerte se expresa, de modo muy particular, en la figura y personalidad mítica de Hermes, dios-mago e inventor de instrumentos musicales ${ }^{15}$, en-

\footnotetext{
${ }^{12}$ Algunos especialistas han destacado la idea de que la diosa minoica ostentara atributos ctónicos y que en el mundo prehelénico pudiera rastrearse el origen de los misterios de Eleusis, que se manifestaría a través del culto a las diosas relacionadas con el grano, la tierra y los muertos. Cfr. Nilsson, M. P., The Minoan and Mycenaean Religión and its survival in Greek Religión, Lund, 1950.

${ }^{13}$ La profesora González Serrano ha señalado, en este punto, una interesante lectura según la cual los corceles alados serían psicopompos, encargados del traslado del difunto a ultratumba, mientras que los caballos reales, representados en el lado opuesto, aludirían al traslado del difunto hasta su última morada (la tumba). Cfr. González Serrano, P., Op. Cit. (nota 10), p.148.

14 Nilsson, M.P., Op. Cit. (nota 12).

15 Para la diferentes interpretaciones de Hermes como dios de la música véase, Molina Moreno, F., «Quinteto para dioses músicos en la mitología griega», Estudios clásicos, Tomo 40, № 113, 1998, pp. 736.
} 
cargado de conducir a los difuntos (o mejor dicho, a sus espíritus) al Hades, en su calidad de dios psicopompo ${ }^{16}$ (fig. 5). Según se narra en el Himno Homérico ${ }^{17}$, el hijo de Maya había robado los rebaños de Apolo; descubierto por su todopoderoso hermanastro, el astuto dios obtuvo el perdón de éste entregándole la lira, instrumento que había fabricado con el caparazón de una tortuga. También su atributo iconográfico más característico, el caduceo, le fue dado por Apolo a cambio de la siringa, también creada por Hermes.

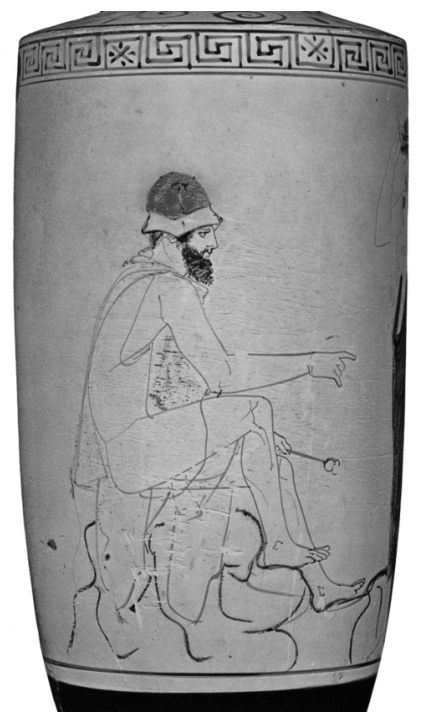

Fig. 5. Hermes psicopompo. Lécito ático de fondo blanco atribuida al Pintor de Phiale. 475-425 a.C. Munich, Antikensammlungen. Archivo Beazley n. 214319.

Los lécitoi de fondo blanco fueron vasos de uso exclusivamente funerario, utilizados como contenedores de perfumes para ritos fúnebres, por lo que su factura es extremadamente cuidada. Los especialistas han señalado que el fondo blanco tiene un simbolismo ritual, imagen de la luz a la que el difunto se dirige tras el óbito ${ }^{18}$. Su decoración está estrechamente ligada a su función, hecho que los hace especialmente interesantes para la reconstrucción de creencias y rituales: es muy frecuente, por ejemplo, que en ellos se representen escenas relacionadas con el más allá, visitas de los familiares del difunto a la tumba, ritos

16 Sobre este tema, véase el interesante trabajo de Díez de Velasco Abellán, F., Los caminos de la muerte. Religión, rito e iconografía en la Grecia Antigua, en http://www.scribd.com/doc/7383613/Francisco-Diez-de-Velasco-Los-Caminos-de-La-Muerte-Religion-Rito-E-Iconografia-en-La-Grecia-Antigua, pp. 16 y ss.

17 Himno Homérico a Hermes, vv. 39 y ss; y vv. 416 y ss. Diodoro Sículo V, 49,1 señala que Hermes regaló la lira a Cadmo el día que éste contrajo matrimonio con Harmonía.

18 Sian Peck, M., «Dining with Death: An Análisis of Attic White-ground Lekythoi and Atenían Notions of Afterlife in Classical Greece, The Joukowsky Institute (Brown University), on line: http://brown.edu/Departments/Joukowsky_Institute/undergrad/prizes/Peck2007.pdf. 
funerarios o mitos y creencias asociadas con la muerte. Estos vasos revelan que debió de existir un intento deliberado de unir el mundo de los vivos con el mundo de los muertos, un deseo de transmitir aspectos del mundo viviente al inframundo, un mundo de sombras, un lugar triste y sin esperanza, en el que no existe la memoria, ni la posibilidad del retorno. Es por ello que en las escenas representadas en estos recipientes se yuxtaponen, con frecuencia, las personas vivientes con el difunto: las pinturas de tumbas (de la superestructura del monumento funerario propiamente dicho) son los eslabones de unión de la vida y la muerte. Los objetos representados sobre las mismas tumbas se han interpretado como regalos del entierro que indican la existencia del culto al muerto. Entre dichos objetos suelen aparecer recipientes cerámicos (kantharoi, lecitoi y otras formas), huevos, granadas ${ }^{19}$, cintas, cofres y ocasionalmente, instrumentos musicales, objetos que también pudieron haber estado en relación con las propias ceremonias de culto funerario.

Destacamos un lécito que se conserva en el Museo de Berlín (fig. 6) cuya pintura muestra la visita de dos figuras a la tumba, dos mujeres, dispuestas según el esquema iconográfico ya citado. Sobre el pedestal del monumento hay cinco recipientes cerámicos y en la parte superior del mismo, un cofre cerrado y un gran bárbiton de seis cuerdas ${ }^{20}$. Las mujeres están realizando un ritual, como indican los característicos gestos de sus manos y la severidad de sus actitudes. La colocación del instrumento musical en lugar preeminente y su exagerado tamaño parecen indicar que pudiera tratarse de un objeto emblemático o sagrado, esencial en los citados ritos. Desde el punto de vista simbólico, sería fascinante imaginar que la capacidad de trasmitir emociones y sentimientos que posee la música, hubiera sido considerada en los rituales luctuosos como uno de los medios más efectivos para conectar el mundo terrenal con el más allá. Por otra parte, como instrumento asociado al culto dionisíaco, el bárbiton pudo, acaso, estar identificado o relacionado con la promesa de renacimiento postmortem.

Apolo y las Musas fueron deidades cuya iconografía estuvo asociada a los contextos funerarios, especialmente como motivo principal en los vasos empleados en los rituales luctuosos. Apolo es el dios de la música y del conocimiento más oculto y las Musas, divinas cantoras de su séquito, son seres divinos enraizados en el origen mismo de la música. Su presencia evoca, metafóricamente, la armonía del Universo. Solas o en compañía Apolo, sus imágenes están asociadas al tránsito al más allá, para sugerir la noción de una eternidad feliz. El himno homérico en honor de las musas y Apolo explica, con sencillez, el sentido de las imágenes de las prodigiosas cantoras, dispensadoras de eterno gozo: Feliz aquel a quien aman las mu-

19 Sobre el simbolismo del huevo y la granada véase, Blázquez Martínez, J.M., Imagen y mito: Estudios sobre religiones mediterráneas e ibéricas, Madrid, Ediciones Cristiandad, 1977, pp. 75 y ss.

20 El bárbiton es un instrumento procedente de Persia, que producía sonidos profundos y graves. Su morfología es casi idéntica a la de la lira de tortuga, aunque sus brazos son notablemente más largos. Por lo común, suele tener siete cuerdas o más. Cfr. Mathiesen, Th. J., Apollo's Lyre: Greek Music and Music Theory in Antiquity and the Middle Ages, Lincoln, University of Nebraska Press, 1999, pp.249 y ss. 


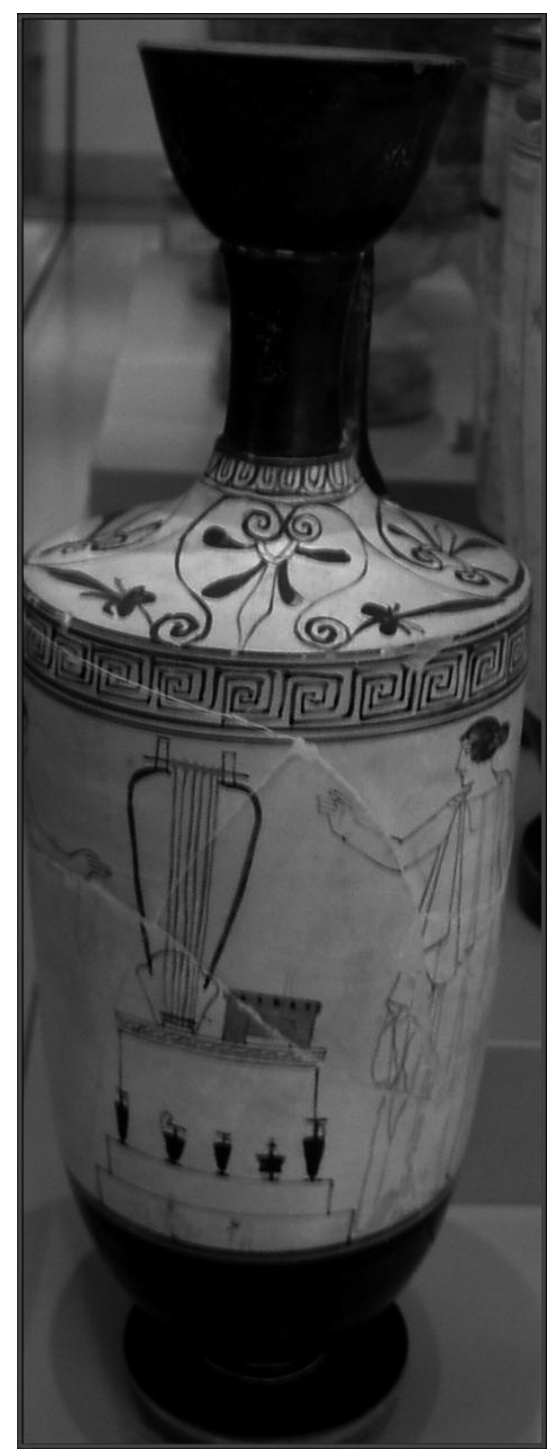

Fig. 6. Lécito ático de fondo blanco. Antikensammlung Berlin; Altes Museum.

sas, dulce fluye de su boca la palabra... Ejemplo de ello es un lécito ático de fondo blanco (440-430 a. C. Munich, Staatliche Antikensammlungen) atribuido al Pintor de Aquiles. La escena representa a una musa, acaso Polimnia, sentada sobre la montaña sagrada del Helicón, tocando con gesto grave una cítara de siete cuerdas, en presencia de otra de sus hermanas (fig. 7). 


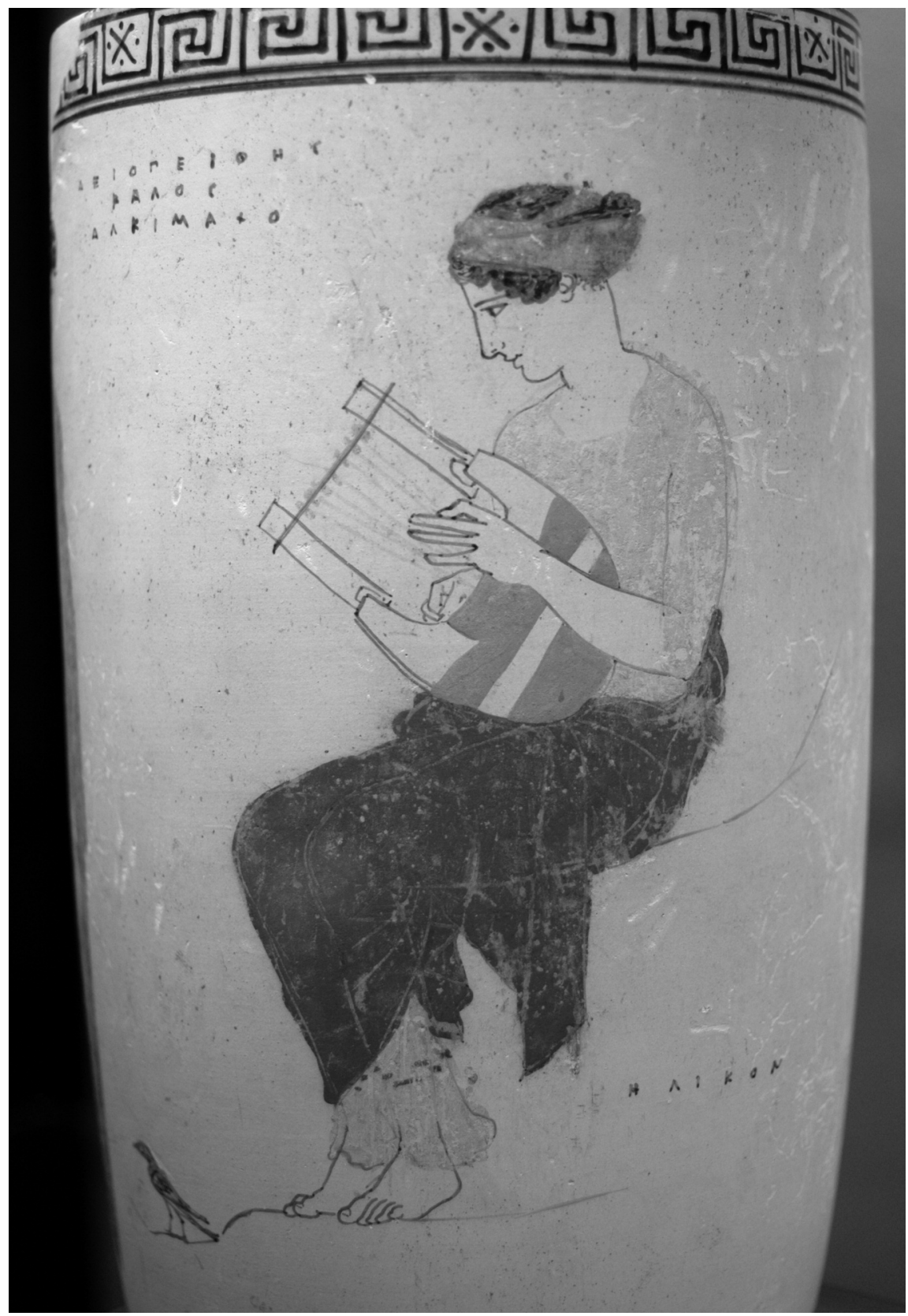

Fig. 7. Musa tocando la cítara. Pintor de Aquiles. Lécito ático de fondo blanco, 440- 430 a. C. Munich, Staatliche Antikensammlungen. 
El tema de las sirenas asociado al mundo funerario es ambivalente y no exento de complejidad ${ }^{21}$. Si bien es cierto que estas maléficas criaturas llevaban al hombre a la perdición con sus funestas melodías, y que su presencia evoca la idea misma de la muerte, desde el S. IV a.C., su representación en los contextos funerarios puede ser entendida como alusión iconográfica a la armonía de las esferas que describiera Platón en el libro décimo de La República: En cada uno de estos círculos había una sirena, que giraba con él, haciendo sonar al mismo tiempo una nota de su voz, e siempre con el mismo tono, de manera que de estas ocho notas diversas, resultaba un acorde perfecto (Platón, La Republica, $X, 616 c-617 d)$.

Así creemos que debe entenderse la representación de estos genios marinos cuando aparecen encarnadas, inmóviles, sobre las rocas (asociación rocas-tumba), como motivo principal en la decoración de los lecitoi (fig. 8). Su apariencia como híbridos de mujer-pájaro evoca, iconográficamente hablando, el Ba egipcio, el alma inmortal; y sugiere, asimismo, el recuerdo de las imágenes de otras criaturas malignas del ámbito egipcio, relacionadas con los muertos, la noche y la oscuridad, como Meruty ${ }^{22}$. Sin embargo, creemos que su fisonomía rígida e inmóvil puede ser interpretada en clave funeraria de manera positiva, como si se tratara de seres relacionados con la armonía del Universo, con la música inaudible del Cosmos, seres protectores del tránsito del difunto y custodios de la inviolabilidad del monumento funerario en el que se hallan.

La Catábasis de Orfeo fue un tema que se puso de moda en el siglo IV a.C., tanto para decorar los vasos cerámicos que formaron parte de ajuares funerarios, como para la ornamentación de estelas funerarias. Orfeo descendió al inframundo y con el poder encantador de su música consiguió ablandar los corazones de Hades y Perséfone, quienes consintieron el retorno de Eurídice con la sola condición de que él no volviera hacia ella su mirada. Orfeo representa, simbólicamente, el concepto de amor como liberación y su figura es, por encima de todo, garantía de la vida en el más allá. La música unida al amor forma en este mito la más inconmensurable de las fuerzas del Universo, capaz de vencer a la misma muerte ${ }^{23}$. Además, como tema fu-

21 Sobre este tema véase, Rodríguez López, M.I., «La música de las sirenas», Cuadernos de Arte e Iconografía, Fundación Universitaria española, Tomo XVI, n.32, 2007.

22 Ogdon, J.R., «Estudios sobre la magia egipcia antigua, II. Probables arquetipos para la bruja (occidental) clásica», en Asociación Española de Amigos de la Egiptologia. Sección de Religión y Mitología. Publicado en 2005.

http://images.google.es/imgres?imgurl=http://www.egiptologia.com/images/stories/religion/magia/magia_egipcia_b/arpias_2.jpg\&imgrefurl=http://www.egiptologia.com/content/view/435/73/\&usg=_ye5VTRUTJ2xoRN6oPvRMjjheA=\&h=345\&w=450\&sz=24\&hl=es\&start=1\&um=1\&tbnid=yi2a6B8Uoj3s7M: \&tbnh=97\&tbnw=127\&prev=/images\%3Fq\%3Dsirenas\%2Begipcias\%26um\%3D1\%26hl\%3Des\%26lr\%3D \%26rlz\%3D1G1GGLQ_ESES296\%26sa\%3DN

http://www.egiptologia.com/images/stories/religion/magia/magia_egipcia_b/arpias_2.jpg

23 El mito confirma la idea de que los muertos no vuelven a la vida, pero también, que el sufrimiento por la pérdida de un ser querido puede producir en sus más allegados la sensación huidiza y fugaz de que éste sigue junto a ellos, como si se tratara de un espejismo o visión interna. La imagen de Eurídice, inasible, desvaneciéndose para siempre en el Hades, tal y como la han recreado los artistas de todos los tiempos, podría ser entendida de este modo. 


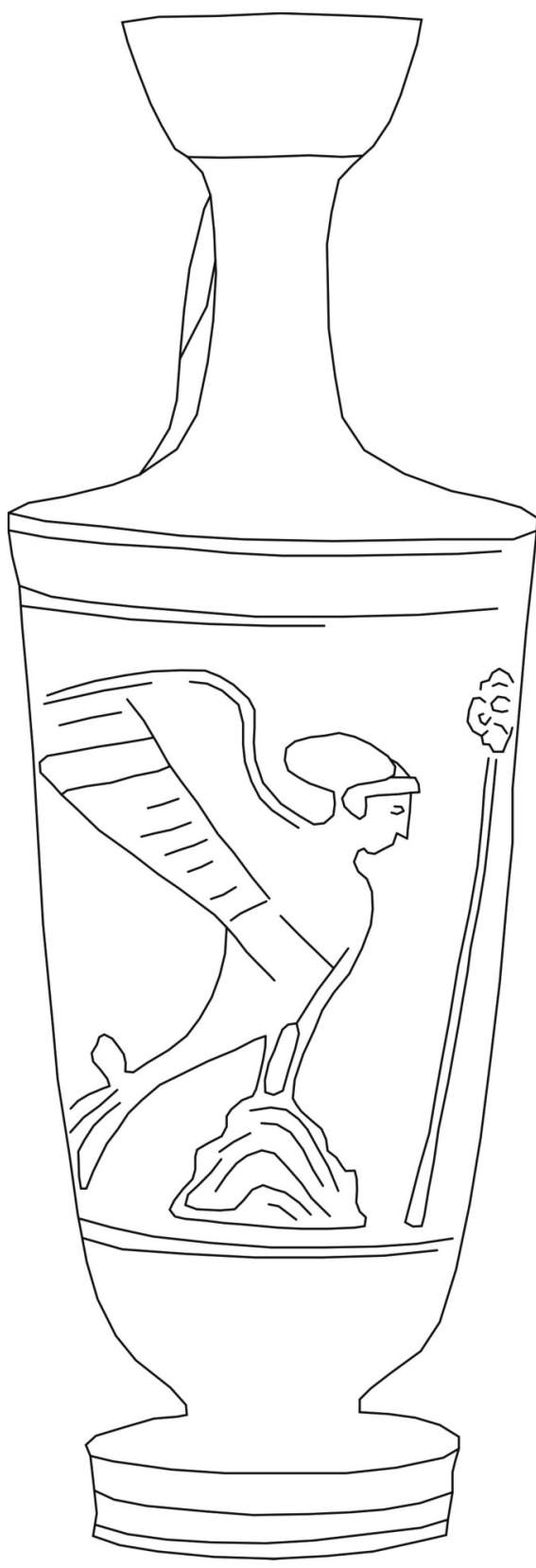

Fig. 8. Lécito ática de figuras negras con representación de sirena inmóvil sobre una roca. S. VI a.C. Museo Arqueológico Nacional de Atenas. 
nerario, el mito de Orfeo liberando a Eurídice era un asunto muy apropiado para una clientela que ansiaba la inmortalidad del alma, a través del Orfismo ${ }^{24}$.

En un conocido relieve de época augustea procedente de Torre del Greco (Museo Nacional de Nápoles), inspirado en un monumento funerario ateniense de finales del siglo $\mathrm{V}$ a.C. (fig. 9), el cantor tracio (identificado por su gorro y por la lira que sostiene en su mano izquierda) no puede superar la condición impuesta por los dioses infernales y se vuelve hacia su amada, a quien Hermes toma de la mano para conducirla por segunda vez, ya irremediablemente, al mundo de las sombras: cabizbajos, los amantes entrecruzan su última mirada y enlazan sus manos con dolor, sin apenas rozarse. De este modo, la historia que nos trasmite la narración mitológica ${ }^{25}$ quedaba concebida y representada por el artista en clave cotidiana, como si fuera una escena de despedida, la fórmula más habitual en relieves funerarios ${ }^{26}$.

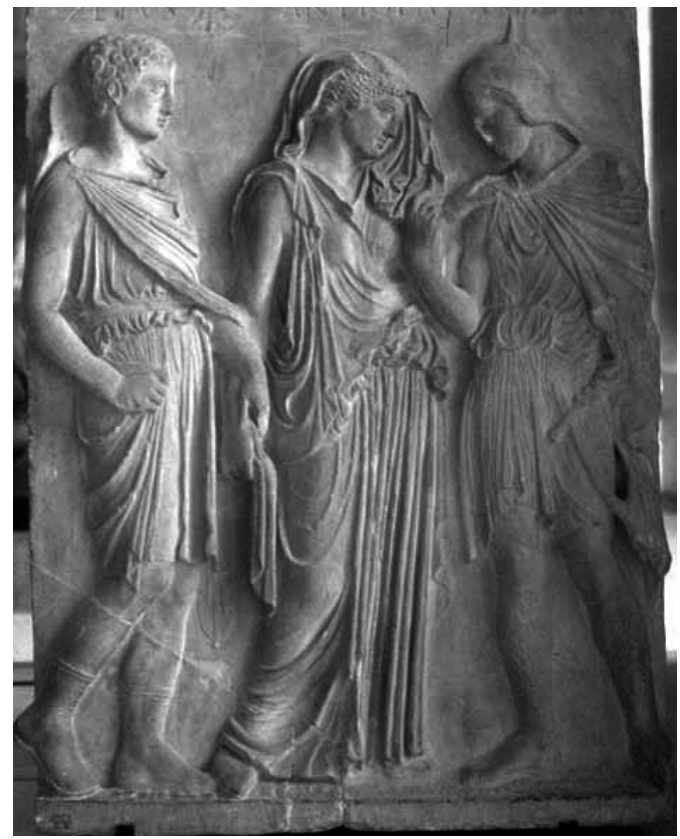

Fig. 9. Relieve que representa a Hermes, Eurídice y Orfeo. S. I d.C. Procedente de una villa romana en Torre del Greco (Campania). Museo Arqueológico de Nápoles.

${ }^{24}$ Bernabé, A., Textos órficos y filosofía presocrática. Materiales para una comparación. Madrid, 2004; "Tendencias recientes en el estudio del Orfismo», Ilu. Revista de Ciencia de las Religiones, 1995, pp.23-32; Herrero de Jáuregui, M., Tradición órfica y cristianismo antiguo. Supervivencia post-mortem e identidad personal en el orfismo, 2007; Bianchi, U., «Misterios de Eleusis. Dionisismo. Orfismo», en Ries J. (ed.), Tratado de antropología de lo sagrado, vol.3, Madrid, 1997.

25 Pseudo-Apollodoro, Bibliotheca 1. 14,Pseudo-Hyginus, Astronomica 2. 7; Ovidio, Metamorfosis, 10. 8 y ss.; Séneca, Hercules Furens 569 y ss. ; Estacio, Tebaida, 8. 21 y ss.

26 González Serrano, P., «Las estelas del adiós», en Más cerca de Grecia, nº 5, 1990, págs. 89-94. 
Las estelas funerarias ponen ante nuestros ojos muy variadas representaciones musicales, cuya interpretación es un asunto complejo. Bailarinas, ménades en éxtasis, sacerdotisas de Isis que agitan sus sistros o escenas de banquete amenizadas por músicos, entre otras, son pruebas de que la música acompaña al difunto (quizá intérprete-músico en su vida terrenal) en su existencia eterna. Interesante ejemplar de lo que decimos es un relieve funerario de la Magna Grecia, conservado hoy en la Gliptoteca de Munich (fig. 10) que representa a un joven efebo en actitud de leer (o cantar $i$ ?) el texto de un rollo que sostiene abierto entre sus manos, mientras un hombre sedente (el difunto), situado frente a él, hace sonar con su lira la música que acompaña a los versos de su joven amigo. La interpretación musical es, en este caso, el procedimiento para representar el último adiós de los personajes, quizás maestro y discípulo unidos por profundos lazos afectivos. También en esta ocasión entendemos que la capacidad de trasmitir emociones y el poder conmovedor de la música sirve para expresar, de forma muy intensa pero contenida, el desconsuelo y la nostalgia de la despedida.

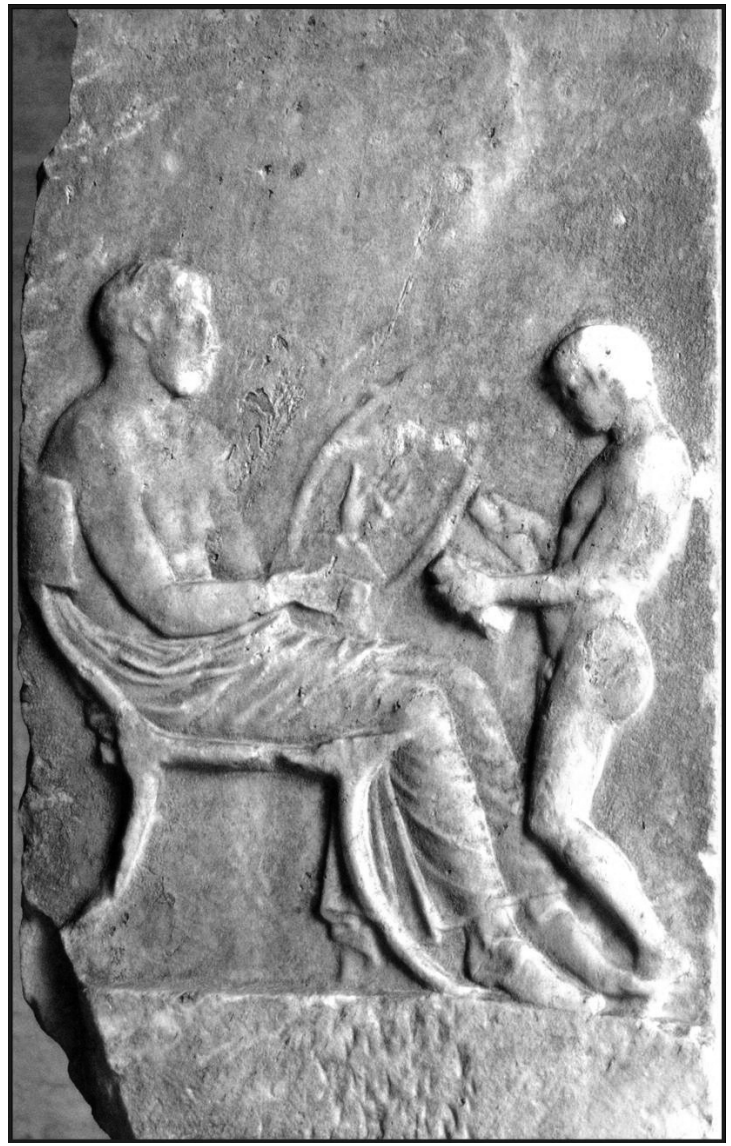

Fig. 10. Relieve funerario con tañedor de lira. Un joven, leyendo sobre un rollo, recita un poema sobre la melodía. Magna Grecia. Circa 420 a. C. Munich, Gliptoteca. 
El Symposion fue otro de los temas funerarios más repetidos en la Antigua Grecia; simbólicamente servía para expresar la unión entre el mundo cotidiano de los vivos con el Banquete funerario del Hades. Dicho banquete funerario expresa la hospitalidad de los Señores del inframundo, es decir, la entrada -sin retorno- en el reino de las sombras. Con el propósito de evocar y rememorar la vida, las escenas de banquete representadas en los contextos fúnebres suelen ser de naturaleza festiva y habitualmente están amenizadas con los sonidos de la lira y del aulós. Los comensales se recuestan, solos o emparejados con efebos ${ }^{27}$ (algunos de ellos intérpretes músicos), sobre las klinai y conversan con vivacidad mientras apuran, gozosos, la bebida de sus cálices (Fig. 11).

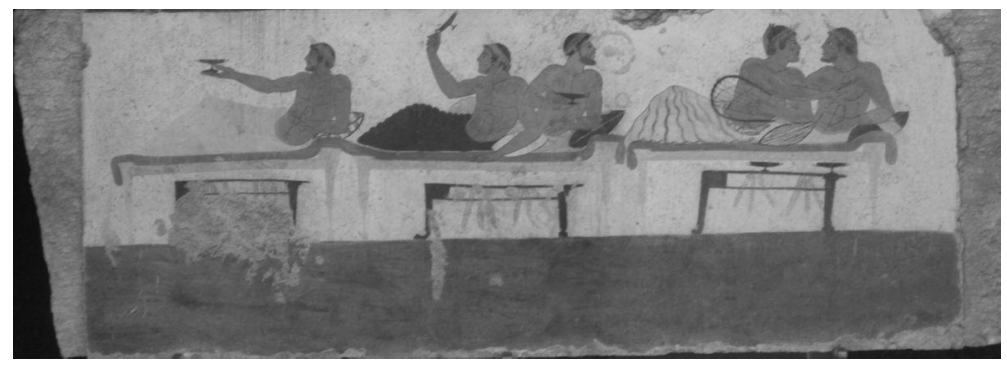

Fig. 11. Pintura de la pared norte de la Tumba del zambullidor. Paestum, Campania, 490-470 a.C. Museo Arqueológico de Paestum.

Es bien sabido que la Grecia clásica forjó la noción de una muerte bella, que con frecuencia fue percibida en las representaciones artísticas como tránsito. Los artistas griegos evitaron la imagen de la expiración de una forma dolorosa o directa y la evocaron a través de escenas diversas que aludían a ella: despedidas, rituales o retratos funerarios..., siendo, como señalábamos, el procedimiento del adiós el más acostumbrado. Sin embargo, entre todos los conceptos forjados para la muerte en el mundo helénico destaca el de la muerte heroica, considerada como una grata muerte ${ }^{28}$. Según dicha concepción, los héroes homéricos eran tenidos como modelos para los hombres, cuyo más vivo deseo pudo ser el de manifestarse de forma similar a dichos arquetipos heroicos y, como ellos, alcanzar la inmortalidad.

Ello podría llevarnos a sugerir que la presencia de instrumentos musicales como parte del ajuar funerario, equiparara, simbólicamente, a los difuntos de elevado rango con los héroes homéricos. Como ejemplo de lo que decimos baste la mención de una de las tumbas de la necrópolis de Metaponto (Basilicata, Magna Grecia), del S. IV a.C., en la que destaca la presencia de una lira (realizada con el

27 Como se verá en las siguientes páginas, el tema del banquete en Etruria suele mostrar parejas heterosexuales ya que los etruscos concibieron el matrimonio monogámico basado en la igualdad, la paridad y el respeto recíproco. Crf. Martínez Pinna, J., «In convivio luxuque: mujer, moralidad y sociedad en el mundo etrusco», en Brocar: Cuadernos de Investigación Histórica, 20, 1996, p. 45 y ss.

28 Díez de Velasco Abellán, F., Historia de las religiones, Tema 13: Muerte y religión, en http://webpages.ull.es/users/fradive/historiacomparada/14muerte/tema14.html. 
caparazón de una tortuga como caja de resonancia) entre los variados objetos que componen el ajuar funerario de los varones de alto rango ${ }^{29}$ (fig. 12).

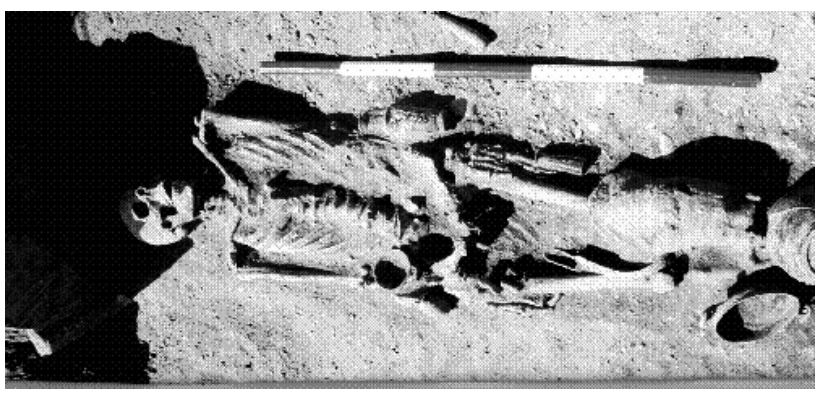

Fig. 12. Tumba de una necrópolis de Metaponto (Italia). S. IV a.C. http://www.colorado.edu/geography/gcraft/warmup/meta1/meta1_f.html

Merece señalarse en este punto, que ya en la iconografía griega del Arcaísmo, Aquiles aparecía enterrado con su lira (fig. 13) El héroe, cuya naturaleza impulsiva y soberbia le llevó a la muerte prematura, tuvo una verdadera vocación musical: había sido adiestrado por el centauro Quirón, el más sabio de sus congéneres, quien le enseñó el manejo de las armas, el arte de la elocuencia, y la música, arte que el invencible pélida habría de cultivar hasta su muerte y cuya práctica le depararía consuelo en los más trágicos momentos de su vida. La instrucción de Aquiles fue el modelo proporcionado por la mitología para la educación de los jóvenes aristócratas griegos, basada, como es bien sabido, en la práctica de las gymnopedias, e inspirada en el equilibrio que proporciona el ejercicio y adiestramiento tanto de las capacidades físicas como de las intelectuales.

\section{ETRURIA}

No sólo en el idioma, también por el estilo de vida y por sus costumbres, los Etruscos son diferentes de todas las otras poblaciones (Dioniso de Halicarnaso) ${ }^{30}$.

Se ha repetido insistentemente la idea de que los etruscos vivieron para la muerte. La Arqueología ha puesto en evidencia que los usos y costumbres de este pueblo estuvieron determinados por sus creencias religiosas y por la noción de supervivencia en el más allá: su preocupación por la muerte y la vida futura inspiró la amplitud de sus prácticas funerarias ${ }^{31}$. Los etruscos concibieron la muerte como la continuación de la vida y fueron muy respetuosos con la creencia de que el muerto olvidado pudiera ser hostil; forjaron la idea de una vida placentera en su última

${ }^{29}$ Crum Sh., Foote K. E., «An introduction to Metaponto and the lago del Lupo» The Geographer's Craft Project, Department of Geography, The University of Colorado at Boulder, 1994. http://www.colorado.edu/geography/gcraft/warmup/meta1/meta1_f.html

30 Dioniso de Halicarnaso, Historia Antigua de Roma, Libro I: 30.

31 Bloch, R., The ancient civilization of the Etruscans. New York: Cowles Book., 1969, p.156. 
morada, materializada ésta mediante tumbas que fueron similares a la casa terrenal; allí los difuntos se regocijarían de la felicidad eterna y no frecuentarían ya nunca más el mundo de los vivos ${ }^{32}$.

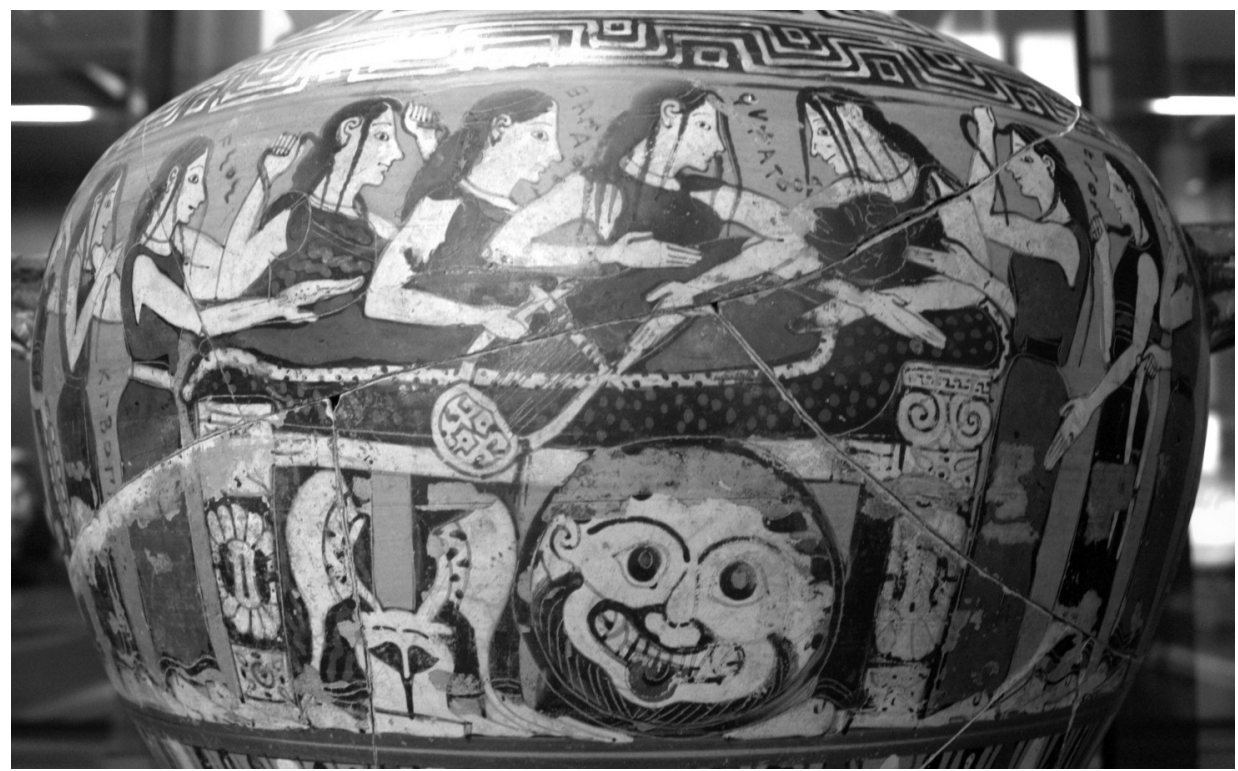

Fig. 13. Tetis y las nereidas Ilorando ante el cadáver de Aquiles. S. VI a.C. Hidria corintia de figuras negras. Museo del Louvre.

Las paredes de las tumbas, especialmente en los siglos VI y V a.C. reflejan este anhelo de eternidad feliz. La riqueza del colorido y la vivacidad de las actitudes es la expresión más adecuada de una dicha perdurable, noción en la que la música habría de adquirir un protagonismo extraordinario ${ }^{33}$. Están dotadas con lo necesario para la supervivencia en el más allá y decoradas con pinturas al fresco que reflejan la existencia cotidiana terrenal ${ }^{34}$. La iconografía de la pintura funeraria etrusca pone ante nuestros ojos un repertorio reducido de temas, entre los que prevalecen los momentos más trascendentales o los más gratos en la vida del difunto, especialmente banquetes en los que los comensales se reclinan en sus lechos (klínal) mientras son servidos y regocijados con música y danzas. En su vertiente

32 Blázquez, J.M., «Representaciones de puertas en la pintura arcaica etrusca» en Trabajos de la Escuela Española de Historia y Arqueología en Roma, 9, 1957, pp.49-74. On line: http://descargas.cervantesvirtual.com/servlet/SirveObras/01472763280147462979079/023017.pdf?incr=1, p. 16.

33 También las pinturas de las tumbas del siglo IV a.C. proporcionan algunos ejemplos de la iconografía del banquete amenizado por la música, como es el caso de la Tumba de los Escudos, en Tarquinia, donde una pareja de músicos acompañan a Laris Velcha y a su esposa en su última morada; sin embargo, la concepción escatológica refleja un pesimismo bien distante a la noción de felicidad ultraterrena que había predominado en las centurias precedentes.

${ }^{34} \mathrm{La}$ creencia de que los muertos utilizaban los mismos objetos que les habían servido en vida procede de Grecia, aunque fue también costumbre adoptada por otros pueblos, como los escitas. Cfr. Blázquez Martínez, J.M., Op.Cit. (nota 32), p.16. 
simbólica, el banquete estuvo unido a la religión y al culto de los muertos y era, en vida, una oportunidad para que los adinerados etruscos exhibieran su status social. En los banquetes más antiguos ${ }^{35}$ sólo participaron hombres, pero en torno al 530 a.C., la iconografía demuestra que los banquetes etruscos aceptaron la presencia de la mujer, hecho que fue muy mal visto por los griegos ${ }^{36}$.

Las tumbas de la necrópolis de Monterozzi, en Tarquinia, ilustran ampliamente sobre la celebración del banquete, un asunto representado desde el siglo VI a.C. ${ }^{37}$ hasta el siglo IV a.C. ${ }^{38}$, siendo más numerosos los ejemplos pictóricos correspondientes al siglo $\mathrm{V}$ a.C. ${ }^{39}$, momento en el que se convirtieron en modelos iconográficos canónicos, sin demasiadas variantes. Entre los citados prototipos clásicos destacamos la llamada Tumba de los Leopardos (Tarquinia), fechada en torno al 470-460 a.C., cuyas pinturas, de sobrio cromatismo, han sido consideradas entre las más bellas manifestaciones del genio etrusco ${ }^{40}$.

El friso central de la pared frontera muestra una escena de banquete que acontece al aire libre ${ }^{41}$. En ella, tres parejas heterosexuales, recostadas sobre sendos lechos ${ }^{42}$, están siendo atendidas por dos jóvenes desnudos y descalzos (posiblemente esclavos). La figura masculina reclinada a la derecha del conjunto sostiene un huevo ${ }^{43}$ en su mano derecha y se lo muestra a la mujer situada junto a él; en la mano izquierda sostiene una $\operatorname{copa}^{44}$.

35 El testimonio iconográfico más antiguo del banquete hallado en Etruria procede de una urna cineraria de Montescudaio (Volterra), de la primera mitad del siglo VII a.C. Cfr. Ceci, F., «El banquete y la ceremonia fúnebre» en Príncipes etruscos, entre Oriente y Occidente, Madrid, Ed. Fundación La Caixa, 2008, p.82.

${ }_{36}$ Cfr. Algunos autores señalan la presencia de la mujer en el banquete etrusco no es anterior al 500 a.C.; Cfr. Penny Small, J., «Eat, Drink and be Merry: Etruscan banquets», en VV.AA., Murlo and the Etruscans. Art and Society in ancient Etruria, University Wisconsin Press, 1994, p. 85 y ss. Tarquinia).

37 Tumba de las Leonas, Tumba de los Vasos pintados, Tumba de la Caza y de la Pesca (todas en

38 Tumba 3242 y Tumba 3626, en Tarquinia.

39 Tumba del Triclinio, Tumba de los Leopardos, Tumba Fiorellini, Tumba del Gallo, Tumba de la Nave, Tumba Pulcella, Tumba del Guerrero, Tumba 5513, tumba 994 y Tumba de la Querciola (todas en Tarquinia).

40 El hipogeo conocido como «Tumba de los Leopardos» fue descubierto en 1875, en la Necrópolis de Monterozzi, en Tarquinia. Tiene cámara única y está cubierta por un tejado a doble vertiente. Véase: Baccolini, G., «La tomba dei Leopardi» en http://www2.fci.unibo.it/ baccolin/tomba leopardi/La tomba dei Leopardi.htm

41 Como antecedente iconográfico merece citarse uno de los más conocidos relieves procedentes del Palacio de Assurbanipal, en Kuyunjik -Nínive- (actualmente en el Museo Británico), el cruel rey asirio, acompañado por la reina Assursarrat, disfruta de un refrigerio al aire libre, bajo un emparrado, mientras es abanicado por músicos y deleitado por la música de un arpa triangular tocada por uno de sus siervos.

42 La posición semitendida de los comensales deriva de mundo griego y del Próximo Oriente, donde fue una costumbre muy difundida. Cfr. Ceci, F., Op. Cit. (nota 35), p.83

43 Símbolo de la inmortalidad: Vide infra.

44 La asociación del huevo y el Kylix fue bastante frecuente en las escenas de banquetes, contextos donde el huevo fue considerado símbolo de la inmortalidad y el Kylix un cáliz que contenía una bebida de naturaleza trascendente (una poción de eternidad). Cfr. Chevalier, J., Dizionario dei simboli, Milán, 1986. 
Los muros laterales están pintados con sendos grupos de sirvientes y músicos que se encaminan hacia la mesa (figs. 14 y 15). En la pared de la derecha son visibles tres figuras y pequeños vestigios de un cuarto personaje prácticamente perdido: son efigies vigorosas que avanzan, plenas de vitalidad y energía, entre arbustos de olivos cargados de frutos ${ }^{45}$; el más próximo a la mesa del banquete sostiene una gran copa en su mano; va seguido por una figura en actitud de sonar un aulós y por otro personaje que lleva en sus manos una lira de siete cuerdas. La última figura, como adelantábamos, no puede ser identificada debido al mal estado de conservación que presenta, aunque el gesto alzado de su brazo indica que pudo ser análoga a la del sirviente que sostiene la copa ya mencionado. La pared de la izquierda, mucho mejor conservada que su opuesta, representa una acompasada y lenta procesión que se dirige, asimismo, hasta la mesa de los comensales. Dicha comitiva está encabezada por dos músicos (un citaredo ${ }^{46}$ y un auletes) seguidos por tres portadores de comida y bebidas ${ }^{47}$.

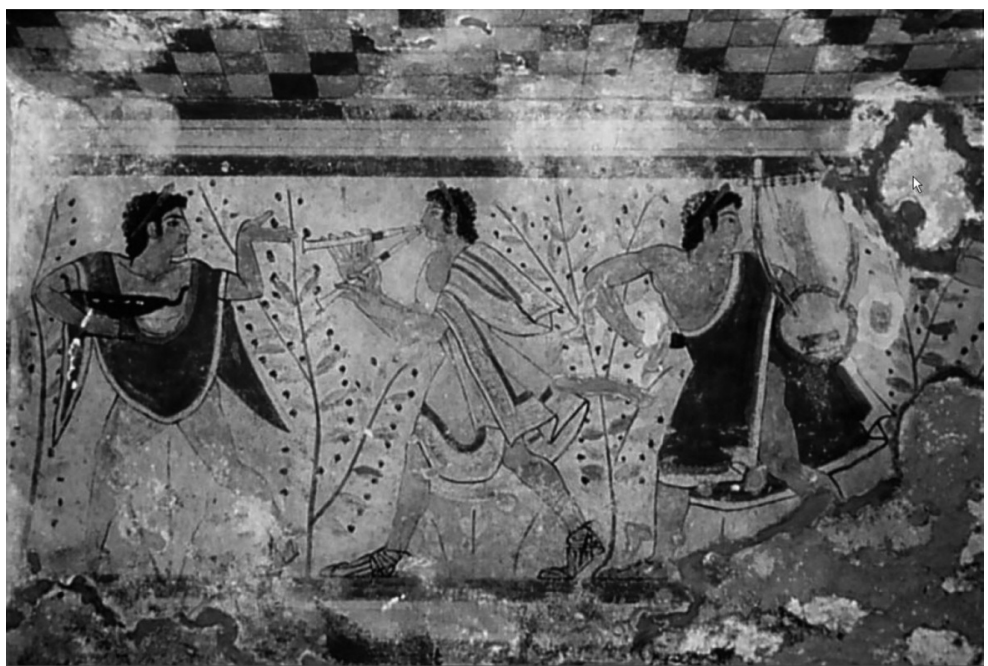

Fig. 14. Detalle de los músicos de la pared derecha. Tumba de los leopardos, Tarquinia.470-460 a.C.

A diferencia de los otros sirvientes (desnudos o sólo cubiertos con un faldellín corto y descalzos), los músicos están ataviados con la tebenna, carac-

45 La abundancia de vegetación podría relacionarse simbólicamente con la vida, es decir, con el renacimiento postmortem.

46 Desde el punto de vista organológico llama la atención el gran tamaño de la cítara, instrumento derivado morfológicamente de la phorminx homérica, que en esta ocasión presenta un elevado número de cuerdas (8-10). Dada la longitud de las cuerdas, el instrumento tendría un ámbito de sonoridad grave, lo que produciría una textura musical muy contrastada al sonar simultáneamente con el registro agudo y la sonoridad estridente del aulós.

47 La Tumba del Triclinio presenta una disposición análoga de los personajes en el espacio (con el banquete en la pared del frente y los músicos y sirvientes en los muros laterales), aunque en ella es más acentuado el carácter orgiástico, visible, muy particulamente, en la ejecución de las danzas. 


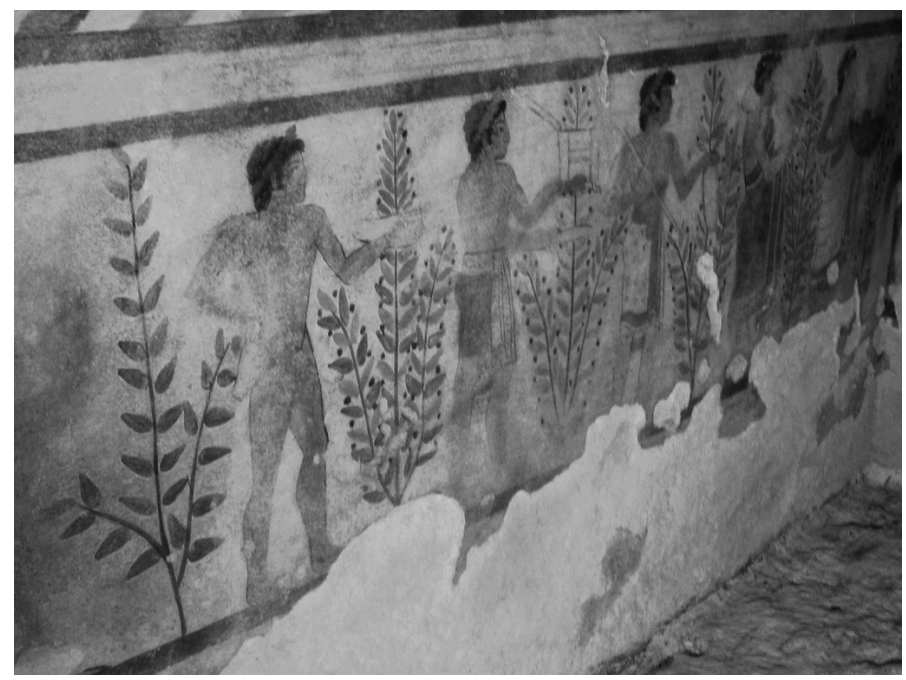

Fig. 15. Detalle de los músicos de la pared izquierda. Tumba de los leopardos, Tarquinia.470-460 a.C.

terística túnica etrusca bordeada con una ancha franja de color y calzan sandalias, hecho que sugiere una consideración o posición social más elevada que la otorgada a los simples esclavos. Tanto en el ejemplo comentado como en otras representaciones, se muestra que la música era interpretada durante el desarrollo del banquete y no tras su conclusión, por lo que formaba parte esencial del mismo

El banquete funerario puede estar unido a las danzas de carácter agonístico, como por ejemplo, en la Tumba del Guerrero (Monterozzi, Tarquinia) ${ }^{48}$, cuya escena principal muestra a dos parejas recostados sobre las klinai, asistidas por músicos y jóvenes sirvientes. En las paredes laterales se representan los juegos funerarios que incluyen diversas competiciones (lanzamiento de disco, jabalina, pugilato...) entre las que merece ser señalada una danza de púgiles que se desarrolla al son de la música interpretada por dos aulodo ${ }^{49}$. Esta escena tiene lugar junto a la mesa en la que aparecen los preciados trofeos destinados a los vencedores. Ha llamado nuestra atención la diferencia de estaturas (o de tamaño) que presentan las figuras de los músicos, que podría interpretarse en virtud de la edad (¿participarían niños-adolescentes y adultos como intérpretes-músicos?) o como signo de la intervención de enanos en

48 Tumba descubierta en 1961, que corresponde al último tercio del siglo V a.C. Cfr. Le tombe etrusche di Tarquinia, en

http://www.canino.info/inserti/monografie/etruschi/tombe_tarquinia/Guerriero/index.htm

49 Otros ejemplos de juegos fúnebres al ritmo del aulós pueden encontrarse en la Tumba del Pulcinella, la Tumba del Citaredo o la Tumba de los Vasos pintados, todas en la necrópolis tarquinense de Monterozzi. 
este tipo de ceremonias ${ }^{50}$. Otra escena musical muestra a un auletes acompañando la danza de un guerrero (o quizás un danzante disfrazado de guerrero), personaje que da nombre a la tumba ${ }^{51}$.

Otra variante del motivo que tratamos la constituyen las pinturas de la Tumba de las Leonas (Monterozzi, Tarquinia) ${ }^{52}$, donde los comensales que asisten al banquete funerario se reclinan en sus lechos en las pinturas de las paredes laterales, mientras que la escena principal, situada en la pared del fondo, muestra una danza ritual: en el centro aparece un enorme cauldron, recipiente ritual engalanado con una guirnalda y a ambos lados del mismo, un citaredo y un auletes que hacen sonar sus instrumentos. A la izquierda, una mujer lujosamente ataviada interpreta una danza con movimientos graves, mientras que en el extremo contrario una pareja de danzantes (hombre y mujer) vestidos de forma más ligera, ejecutan una danza de pasos más ágiles. Bajo este friso, discurre, a lo largo de todo el hipogeo, otro friso inferior decorado con delfines que saltan gozosos sobre la superficie marina ${ }^{53}$.

Otro interesante ejemplo de danza agonística se halla en las pinturas de la Tumba Cardarelli (Monterozzi, Tarquinia) ${ }^{54}$. En la pared del fondo, afrontados a ambos lados de una puerta (el umbral de acceso al inframundo o el acceso a la tumba-morada del difunto) ${ }^{55}$ dos instrumentistas de grave porte (auletes y citaredo) hacen música (fig.

50 Es bien sabido que en el mundo egipcio y oriental, algunos enanos sirvieron como músicos, especialmente como danzarines asociados a los funerales, y que por su particular fisonomía fueron asociados con el nacimiento y el renacimiento. Cfr. «The Dancers - Professional bureau, Foreign dancers, Dancing dwarfs, Pygmies, A prince sends the khener to a funeral, Story of a khener», en http://encyclopedia.jrank.org/articles/pages/50/The-Dancers.html. Por otra parte, el dios Bes fue considerado patrón de los nacimientos y su presencia está asociada a la música y a la danza. Cfr. Arroyo de la Fuente, A., «Evolución iconográfica y significado del dios Bes en los templos ptolemaicos». UNED. Espacio, Tiempo y Forma. Serie II, t. 19-20, 2006-2007, pp. 13-40.

51 Interesantes ejemplos de danzas unidas juegos funerarios pueden estudiarse, asimismo, en la tumba de los Vasos Pintados y en la tumba Pulcinella, ambas en la necrópolis tarquinense de Monterozzi.

52 Descubierta en 1874, corresponde al siglo VI a.C. Véase: http://www.canino.info/inserti/monografie/etruschi/tombe_tarquinia/Leonesse/index.htm

53 La presencia del agua y los delfines en los monumentos sepulcrales puede asociarse al tránsito al más allá, si se considera el mar como elemento de transmigración de las almas. Cfr. Rodríguez López, M.I., Mar y Mitología en las culturas mediterráneas, Madrid, 1999, p.28.

54 http://www.canino.info/inserti/monografie/etruschi/tombe_tarquinia/Cardarelli/index.htm

55 La puerta representada en la Tumba Cardarelli es idéntica a las que aparecen en la Tumba de los Augures y la Tumba de las Inscripciones, ambas fechadas en torno al $550-520$ a.C. La interpretación de este motivo no es del todo clara. El profesor Blázquez estudió en su día las interpretaciones dadas al respecto y de acuerdo con Pallotino y Poulsen, realizó una lectura iconográfica que sostenía que la representación de la puerta, en época arcaica, fue concebida como un «acceso al resto de la casa real del muerto, de la que la sepultura es fiel reproducción», ya que en el período arcaico se tenía la creencia de que el muerto residía en la tumba para toda la eternidad. Cfr. Blázquez Martínez, J.M., Op. Cit. (nota 32), p.22. Sin embargo, nos inclinamos a pensar que pudo existir una ambivalencia semántica en lo que se refiere a la supervivencia del muerto: la tumba fue concebida como casa de eternidad, es decir, como lugar donde el alma del difunto residiría en su existencia ultraterrena. A juzgar por la documentación iconográfica, la concepción del sombrío y lúgubre Hades griego, como destino de las almas no fue introducida en Etruria hasta fines del siglo V a.C., pero para existir eternamente, en una vida no terrenal, el alma del difunto debía realizar un cambio o transmigración, tanto si fuera a permanecer para siempre en su casa-tumba como si su meta fuera el reino de los muertos. El concepto de la «otra vida» es, por tanto, una noción cargada de una notable ambigüedad de significado, por lo que su interpretación se nos escapa. 
16). La explicación de este motivo no es sencilla. Según las creencias primitivas, el muerto permanecía en la tumba para toda la eternidad, por lo que la presencia de la música en el umbral de la puerta (que simboliza a la propia tumba) ${ }^{56}$ pudo haber significado la continuación de esta vida, ya que su ausencia (el silencio) es, asimismo, la inexistencia de la vida. Sin embargo, pudiera pensarse que la función de estos dos músicos, de gesto grave y situados junto a vasos rituales, estuviera relacionada con los ritos fúnebres, o que su misión fuera la de aplacar a los demonios que pueblan el averno y hacer que el tránsito del alma pudiera experimentarse sin dificultades ${ }^{57}$. El muro de ingreso está ocupado por dos atletas de fornida complexión, cuyas actitudes evocan la danza, mientras que en los laterales se representan escenas de juego (kótabbos $)^{58}$ y danzas acompañadas por el sonido del aulós.

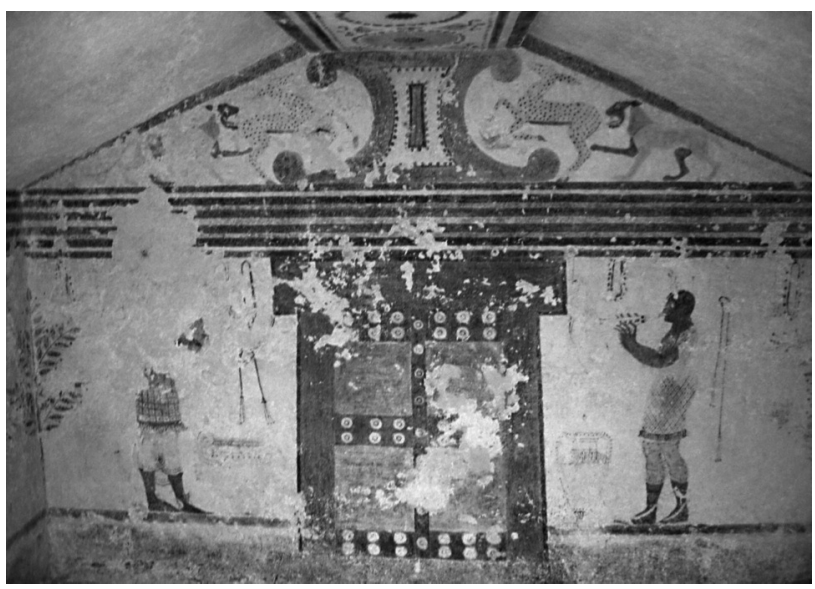

Fig. 16. Muro trasero de la Tumba Cardarelli. Músicos intérpretes flanqueando una puerta.

La misma gravedad domina en la Tumba del Barón, ejemplo significativo de la madurez de la pintura etrusca arcaica y cuya lectura iconográfica resulta muy compleja. En el friso principal un personaje barbado, con oscuro manto terciado sobre su pecho, abraza a un joven aulodés (o auletes) ${ }^{59}$ y dirige su Kílix (en señal de

56 También en la tumba Della Pulcella (Monterozzi, Tarquinia), de fines del siglo $\mathrm{V}$ a.C., la pared de fondo presenta una edícula excavada para contener el lecho fúnebre. A ambos lados de éste, un citaredo y otro personaje (un auletes $i$ ?) interpretan sus melodías, mientras en las paredes laterales del hipogeo se desarrolla un banquete en el que se advierte la presencia de instrumentos musicales (una lira y un tympanon). Cfr. http://www.canino.info/inserti/monografie/etruschi/tombe_tarquinia/Pulcella/index.htm

57 Así parece sugerirlo la iconografía que presentan algunas urnas cinerarias en las que un demonio femenino actúa como custodio de la puerta del Hades -una puerta arqueada-; en algunos casos, las urnas cinerarias presentan una puerta flanqueada por dos músicos cuyas melodías, como señaló Sheffer, estarían destinadas a serenar el ánimo de las criaturas infernales. Cfr. Sheffer, Ch., «The Arched Door in Late Etruscan Funerary Art», en VV.AA., Op. cit. (nota 36), p. 196 y ss. Fig.18.6.

58 El kótabbos era un juego que consistía en hacer girar las copas llenas de vino y tenía función adivinatoria relacionada con el amor.

$59 \mathrm{Su}$ juventud se vislumbra en virtud de su menor tamaño. La actitud del personaje masculino que lo cubre con su brazo pudiera sugerir que está presentándolo o introduciéndolo ante la dama, que ha sido identificada como la difunta o como una sacerdotisa. 
ofrecimiento) a una elegante dama que realiza un expresivo ademán de salutación. Los personajes están aislados por un motivo vegetal estilizado. Separados por unos arbustos, sendos jinetes completan la escena por ambos lados. En los muros laterales se figuran caballos y jóvenes que contienen sus bridas, mientras saludan a la dama de la escena principal. En el frontón, dos hipocampos navegan entre delfines. Estas pinturas han sido tradicionalmente interpretadas como el homenaje de despedida que recibe la difunta por parte de su marido y de sus hijos, aunque todavía hoy no existe una interpretación satisfactoria del conjunto ${ }^{60}$.

En la escena principal de la tumba Francesca Giustiniani (necrópolis de Monterozzi, Tarquinia), de mediados del siglo V a.C., dos bailarines (un hombre y una mujer vestida lujosamente) ejecutan una agitada danza guiados por el sonido de un aulós tocado, en esta ocasión, por una figura femenina. El aulós es un instrumento cuya interpretación era, a juzgar por las fuentes iconográficas, una prerrogativa propia del sexo masculino, por lo que esta pintura resulta de gran interés, como documento único y excepcional. La danza fúnebre precede a una biga de caballos alados, quizá dispuestos para servir de montura a la difunta (la danzante ¿?) en su viaje al más allá (fig. 17).

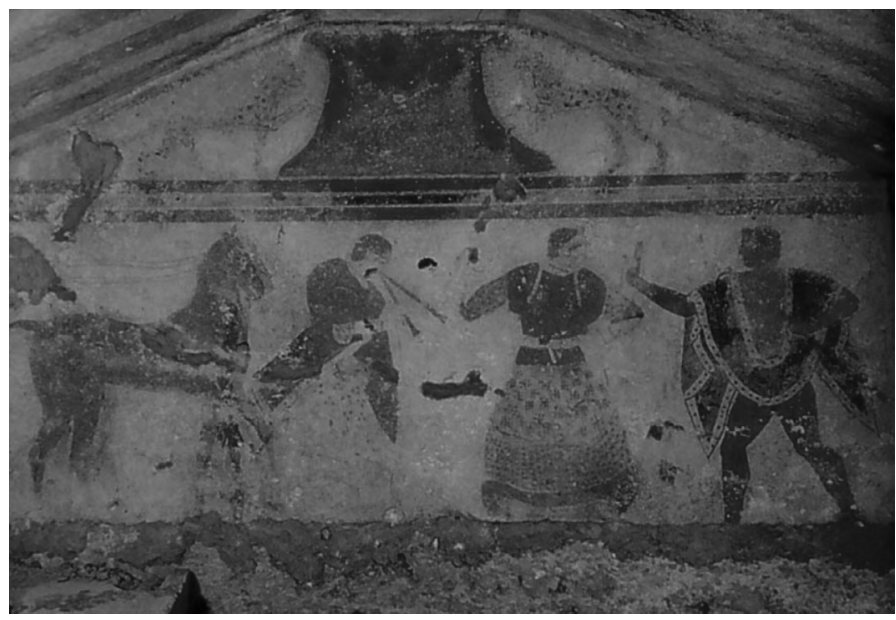

Fig. 17. Pared de fondo de la tumba Francesca Giustiniani, en Tarquinia.

Algunas representaciones exhiben danzas agonísticas relacionadas con los juegos funerarios celebrados como parte de las exequias del difunto, siempre siguiendo el ritmo marcado por los aulodoi, como evidencia la pintura de una tumba hallada en Grotta della Simia, Corneto, de hacia el 500 a.C ${ }^{61}$ (fig. 18).

60 Según otras hipótesis, las pinturas pueden ser interpretadas en clave mitológica y representan la despedida de la difunta a sus seres queridos antes de que los Dioscuros la acompañen al mundo subterráneo. También se ha señalado que estas escenas simbolizan el tránsito entre la vida (expresada mediante el caballo rojo) y la muerte (el caballo negro).

61 The Dance: Historic Illustrations of Dancing from 3300 B.C. to 1911. Project Gutenberg .http://www.archive.org/details/thedancebyananti17289gut 
Merece señalarse que uno de los dos auletes que marcan los pasos con la sonoridad de sus instrumentos es un personaje enano, de extraña fisonomía y particular indumentaria de tipo oriental.

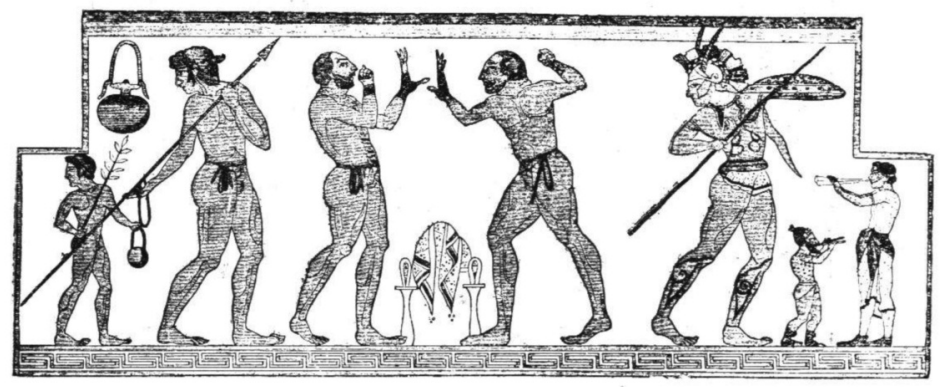

Fig. 18. Danza-agón. Grotta della Simia, Corneto. Circa 500 a.C.

Las danzas funerarias representadas en el ámbito de influencia etrusca fueron muy variadas, realizándose ante el cadáver o ante la tumba tras el sepelio, como pone de manifiesto la iconografía de las tumbas de Campania. Una sepultura localizada en las proximidades de Albanella (Salerno, Campania), en las postrimerías del siglo IV a.C. o principios de la centuria siguiente (fig. 19), representa una danza ante el lecho fúnebre de una mujer de alto rango: dos figuras femeninas declaman, con acusada gestualidad, las lamentaciones o cantos fúnebres, acompañadas por el sonido de un auletes enano; una mujer situada a los pies del catafalco fúnebre, ejecuta una danza ${ }^{62}$, mientras otra figura femenina, elegantemente ataviada, contempla desde su asiento el desarrollo del ritual y sostiene en su mano una corona. En otras ocasiones, cogidas de las manos y con la cabeza velada, las mujeres interpretaban una danza funeraria, describiendo un movimiento circular en torno a la tumba, tal y como muestran las pinturas de una tumba de Ruvo di Puglia, del 350 a.C. (Nápoles, Museo y Galería Nacional de Capodimonte) (fig. 20).

El panorama de las danzas funerarias que venimos perfilando de forma sucinta en estas líneas se completa con las danzas desenfrenadas u orgiásticas, como las que pueden contemplarse en la Tumba de las Bacantes, en Tarquinia (510 a.C.) o en la Tumba del Triclinio (Tarquinia, 470-460 a.C.), donde los danzantes, presos del éxtasis, ejecutan movimientos violentos y exagerados; en otros casos, la danza se asocia a los juegos eróticos, como sucede en la Tumba de la Fustigación (Tarquinia, siglo V a.C.) ${ }^{63}$.

62 Un paralelo iconográfico casi idéntico de esta danza puede encontrarse en la «Tumba de la losa pintada» en Paestum, del siglo IV a.C., cuyas pinturas se conservan en el Museo Arqueológico de Paestum. Cfr. Bianchi Bandinelli, R., Los etruscos y la Italia anterior a Roma, Madrid, 1974, ff. 274 y 275.

63 Moscatelli, G., L’Eros degli Etruschi, Alle origine dell erotismo mediterraneo, en http://www.canino.info/inserti/monografie/etruschi/eros_etruschi/eros_etruschi_4.htm 


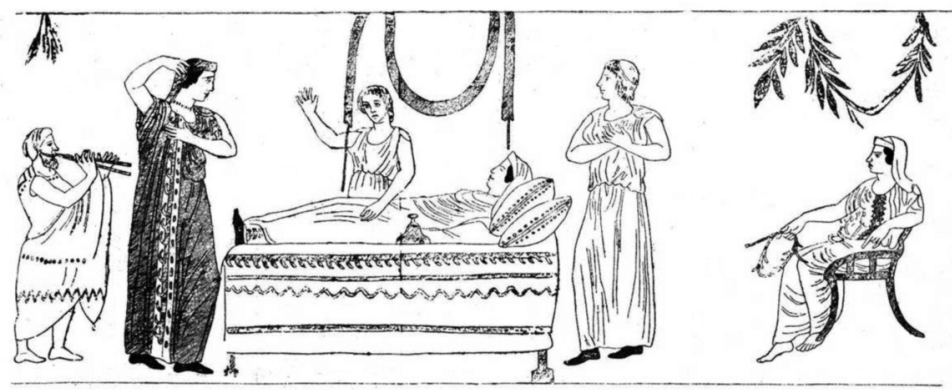

Fig. 19. Danza funeraria en las exequias de una mujer. Tumba pintada en las proximidades de Albanella (Campania). S. IV-III a.C.

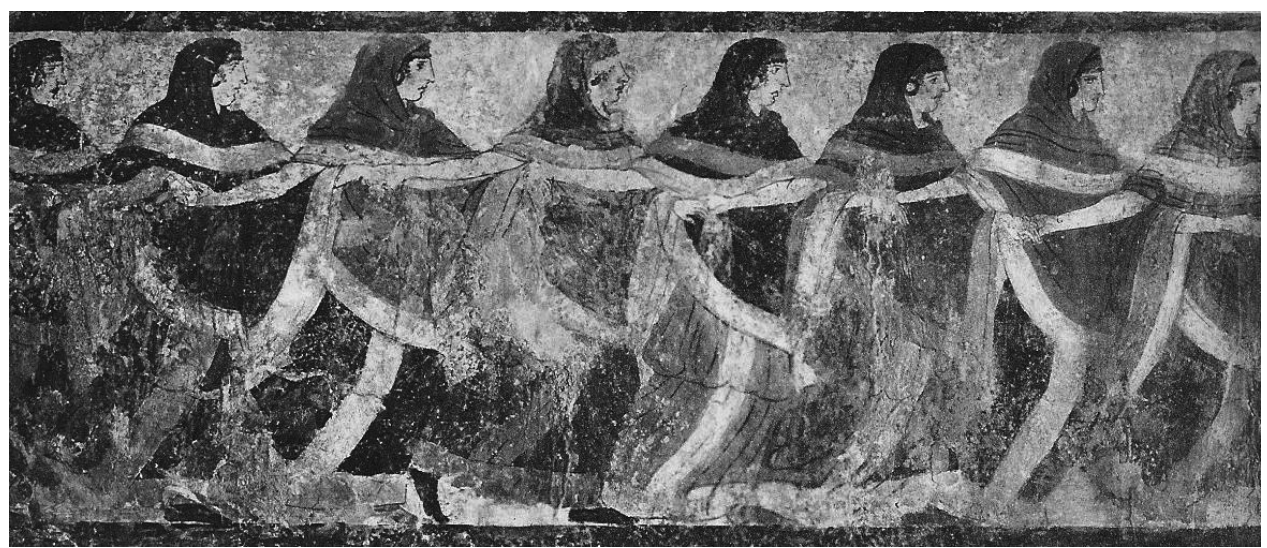

Fig. 20. Pintura de una tumba de Ruvo di Puglia , 350 a.C. Museo y Galería Nacional de Capodimonte.

Las pinturas de la llamada Tumba Golini, en Orvieto64 (Velzna, la llamada Volsinii Veteres de los romanos), realizadas en la segunda mitad del siglo IV a.C., contienen escenas de la llegada del difunto al Hades, y del Banquete ofrecido en su honor, en presencia de los dioses. Son interesantes, en el marco de este trabajo, algunos aspectos de dicha tumba. Señalamos en primer lugar, que las escenas de preparación del banquete, dotadas con un notable sentido naturalista, han sido concebidas como escenas de género, donde los sirvientes aparecen industriosos y afanados en sus diversas tareas. Entre ellos se encuentra una figura cuya posición de las manos sugiere que podría tratarse de un auletes ocupado en la preparación de su instrumento, para que pudiera estar listo en el Banquete.

64 Descubierta en 1963 en la Necrópolis de los Siete Caminos y hoy reproducida en el Museo Arqueológico de Orvieto. Feruglio, A.E., (e.a.), Pittura etrusca a orvieto. Le tombe di settecamini e degli Hescanas a un secolo dalla scoperta. Documenti e materiali, Roma, Edizioni Kappa, 1982. 
Asimismo, la iconografía musical de esta tumba es bien notable por la presencia de instrumentos «altos» (instrumentos de sonoridad potente) de metal: El cornu aparece en la escena en la que el difunto montado en un carro llega al Hades precedido por un demonio femenino alado (fig. 21). La presencia de los instrumentos de viento-metal asociada a los contextos funerarios habría de tener, como es bien sabido, larga pervivencia en el mundo occidental, ya que su sonoridad poderosa resultaba adecuada a la llamada del Juicio Final, como demuestran los ángeles trompeteros de los Beatos miniados y otros muchos ejemplos del arte medieval europeo.

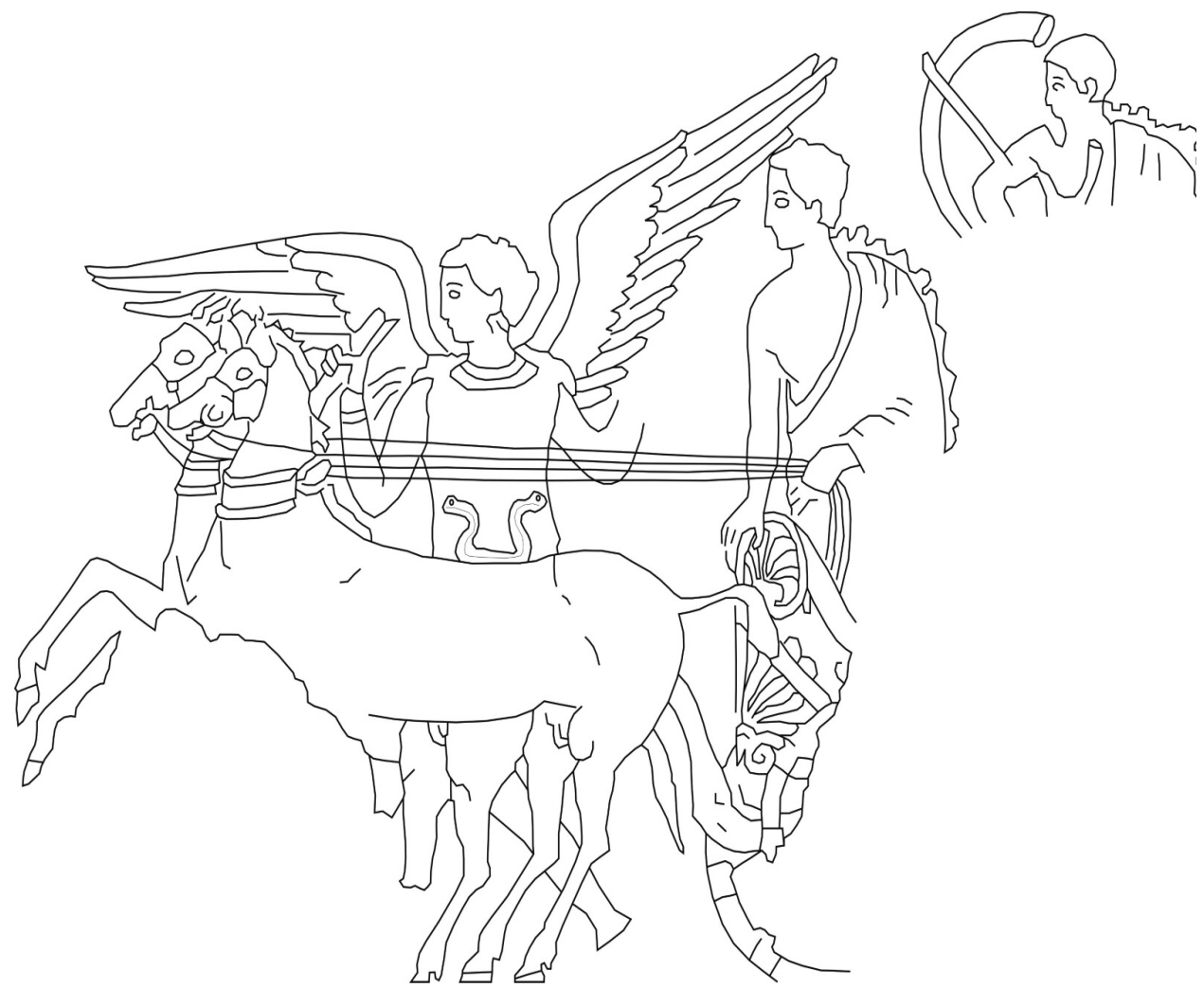

Fig. 21. Orvieto, detalle de una de las pinturas de la Tumba Golini que muestra la llegada del difunto al Hades, precedido por un demonio femenino alado.

En la tumba de los Hescana, también en las proximidades Orvieto (S. IV a.C.) (fig. 22), el tema principal de la decoración pictórica lo constituye el viaje del difunto a ultratumba y los ritos y banquetes que lo acompañan. Las paredes muestran cortejos de jóvenes y otros personajes de dudosa interpretación entre los que se hallan tres personajes masculinos ataviados con traje blanco sacer- 
dotal que portan, respectivamente, un $\operatorname{cornu}^{65}$ y un lituus ${ }^{66}$, y el tercero dos varas $^{67}$. Los instrumentos musicales representados se asocian al ámbito de la religiosidad y Disciplina etrusca ${ }^{68}$.

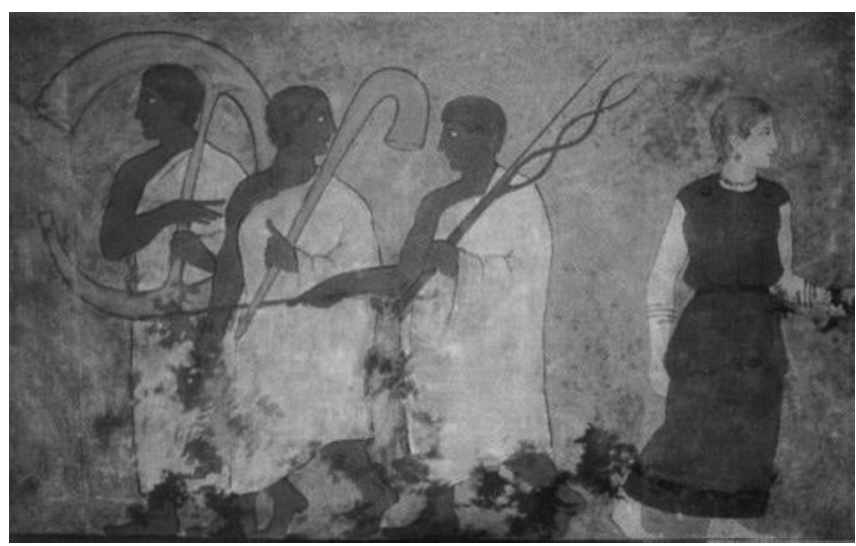

Fig. 22. Detalles de una de las escenas pintadas en la Tumba de los Hescana, en Orvieto. http://www.comune.porano.tr.it/it/tombe_golini_e_degli_hescana.html

Paralelos iconográficos de los asuntos y motivos comentados en las líneas precedentes fueron, asimismo, temas decorativos recurrentes en muy numerosas y diversas piezas de naturaleza funeraria, sarcófagos y urnas cinerarias principalmente. La presencia de la música y los músicos (instrumentistas o danzantes) fueron objeto de reinterpretaciones muy variadas en manos de los artesanos etruscos de diferentes lugares, siempre asociados a los contextos funerarios. Fi-

65 El cornu es un instrumento de viento utilizado por el ejército y los sacerdotes. Es un instrumento grande y de sonoridad poderosa, cuyo pabellón sonoro se incurva formando casi la forma de una letra G mayúscula, con una barra central que sirve para sostener el instrumento a la conveniencia del intérprete. No tenía tapones para ajustar la sonoridad a cualquier modo concreto, de tal suerte que la serie entera de notas se podría reproducir sin llaves ni agujeros, sólo por la modificación de la respiración y la presión de los labios en la boquilla. Probablemente, y según puede deducirse de las descripciones dadas por los poetas, su sonoridad era como una octava más grave que la trompeta. Era habitual que formara dúo con el lituus: «Sonuit reflexo classicum cornu, Lituusque adunco stridulos cantus. Elisit aere.» (Seneca, Oedipus,734). Cfr. Benjamin Jowett, M.A., «Cornu», en Dictionary of Greek and Roman Antiquities, John Murray, Londres, 1875, pp. 358 y 359, en http://penelope.uchicago.edu/Thayer/E/Roman/Texts/secondary/SMIGRA*/Cornu.html.

66 El lituus es un báculo asociado a los augures, a quienes servía para designar el espacio destinado a la casa del dios, sirviendo para liberar dicho espacio de los malos espíritus. Cfr. Mura Sommela, A., «La religión y la arquitectura sacra» en VV.AA. (2008), n.123. Pero es también un tipo de trompeta curvada en su extremo, un tipo peculiar de trompeta sacerdotal que en Roma habría de ser usada por el ejército. Cfr. William Ramsay, M.A., «Lituus», en Dictionary of Greek and Roman Antiquities, John Murray, Londres, 1875, p.709 http://penelope.uchicago.edu/Thayer/E/Roman/Texts/secondary/SMIGRA*/Lituus.html

67 La peculiar morfología de dichas varas, una recta y otra retorcida, puede estar en relación con la serpiente, símbolo universal de resurrección y sanación.

68 Sobre este tema Véase Montero Herrero, S., «Astrología y «Etrusca disciplina»: contactos y rivalidad», en $\mathrm{MHNH}$ : revista internacional de investigación sobre magia y astrología antiguas, n. 1, 2001, pp. 239-260. 
nalizamos nuestro discurso con la sola mención de algunos de dichos ejemplos: un cipo funerario procedente de Chiusi, del 480 a.C. (Roma. Museo Barraco) ${ }^{69}$ que muestra una escena de la lamentación fúnebre sobre el cadáver, acompañada por el sonido de un auletes, o el sarcófago hallado en la «Tumba de los Sarcófagos» (de Caere), hoy en el Museo Gregoriano Etrusco, cuyo frente muestra una procesión funeraria precedida por sacerdotes y músicos y es claro precedente icónico del célebre relieve de Amiternum, hoy en el Museo Nazionale d Abruzzo (L Aquila), obra romana de la segunda mitad del siglo I a. $\mathrm{C}^{70}$., o, entre otras, las urnas funerarias de Chiusi.

\section{CONCLUSIONES}

Hemos percibido a través de estas líneas la importancia que tuvo la música en el marco de los contextos funerarios, tanto por su presencia en las ceremonias y rituales fúnebres como porque con ella se evocaba la vida o se hacía más fácil el tránsito al más allá. Todo parece indicar que esta asociación música-muerte-vida fuera una costumbre arraigada desde el Neolítico, estando plenamente atestiguado por la Arqueología desde el Bronce Antiguo.

La documentación iconográfica del mundo prehelénico nos informa sobre el hecho de que la música fue esencial en el ritual funerario, dado que sacralizaba las ceremonias funerarias, y les otorgaba solemnidad, gravedad, empaque y todo el dramatismo que dichas circunstancias requerían. Hemos podido observar que la lira fue un instrumento que sirvió para acompañar cantos y ofrendas, mientras que el aulós fue utilizado, con más frecuencia, como comparsa de las danzas y actos sacrificiales propiamente dichos. La lira es un instrumento asociado a hombres y mujeres indistintamente, mientras que el aulós parece haber sido, en la mayoría de los casos, un instrumento interpretado por varones.

Los mitos griegos explicaron, en parte, el misterio de la muerte. Hermes, Apolo y las Musas, Orfeo o las sirenas, entre otros, estuvieron unidos simbólicamente a los medios funerarios para satisfacer el deseo de conocimiento y comprensión del tránsito. La unión simbólica entre el mundo de los vivos y el mundo de los muertos quedó plasmada en las escenas de los lecitoi de fondo blanco, vasos de uso funerario, y en los relieves de las estelas funerarias donde las escenas de despedida, ocasionalmente una despedida de carácter musical, fueron muy habituales. La muerte bella (como despedida) y la muerte heroica, considerada como la mejor de las muertes, son los conceptos fundamentales de esta cultura, que también desde mediados del siglo V a.C. compartía la esperanza de la vida futura. El poder encantador de la música y su capacidad de conmover hacen de ella un poderoso aliado capaz de vencer a la muerte, según se expresa en algunos mitos griegos.

69 Elvira Barba, M.A., Blanco Freijeiro, A., Etruria y Roma Republicana, Madrid, 1989, p.48.

70 Franchi, L., «Rilievo con pompa funebree rilievo con gladiatoria al Museo dell Aquila» en VV.AA., Sculture romana nell area sabelica, Studi Miscellanei, 10, Roma, 1966, pp. 23-32. 
El deseo de una eternidad feliz que se intuye en la cultura griega, se acrecienta en la cultura funeraria etrusca, dominada por la joie de vivre. Las firmes creencias sobre el más allá hicieron que la muerte fuera concebida como una continuación dichosa de la existencia terrenal, aunque a partir del siglo IV a. C., la concepción escatológica se tornara más sombría ${ }^{71}$. La iconografía etrusca, más prolija, nos permite vislumbrar múltiples aspectos: Banquetes y juegos funerarios, danzas rituales y música son aspectos omnipresentes en los monumentos mortuorios. Es notable la variedad de instrumentos musicales utilizados (liras, Khytara, auloi, crotala, tympana, tibiae, trompetas, trompas...) y la pluralidad de danzas que pone ante nuestros ojos la iconografía del arte etrusco (danzas rituales, danzas orgiásticas, danzas ante el cadáver, danzas en el sepelio...).

La mayoría de los instrumentistas son hombres. Los aulodoi, salvo en la excepción de la citada tumba Francesca Giustiniani, en la necrópolis de Monterozzi, son siempre varones: algunas veces, enanos, otras adolescentes y en la mayoría de los casos, hermosos jóvenes que actúan como sirvientes para alegrar con sus sonidos la celebración de los banquetes. Asimismo, son músicos varones los citaredos, y los tañedores de lira en Etruria, mientras que en las danzas intervienen personajes de ambos sexos, siendo algo más nutridas las representaciones de bailarinas (a veces sosteniendo en sus manos los crótalos) o de parejas formadas por figuras de ambos sexos.

La iconografía de la muerte pone ante nuestros ojos una serie de prácticas que deben ser entendidas, a nuestro juicio, desde dos perspectivas: individual y colectiva. Individualmente, la presencia de la música pudo acrecentar la expresión del sentimiento de dolor y ayudaría a su exteriorización mediante las lamentaciones. Y desde el punto de vista colectivo, la música formaría parte de un ritual, de un conjunto de prácticas y usos sociales que estuvieron muy arraigados en relación con las creencias de las civilizaciones antiguas.

En virtud de su poder de evocación la música pudo concebirse, en el mundo antiguo, como nexo simbólico de unión entre el mundo de los vivos y el mundo de los muertos, dos niveles de existencia que quedaron asidos para siempre a través de la inmaterialidad del sonido. Desde la Antigüedad hasta nuestros días el poder de la música ha permanecido inmutable: su ausencia significa la oscuridad y el silencio de la muerte y su presencia, evoca la vida y sus más venturosos instantes.

\section{BIBLIOGRAFÍA}

ARROYO DE LA FUENTE, A., «Evolución iconográfica y significado del dios Bes en los templos ptolemaicos», UNED. Espacio, Tiempo y Forma. Serie II, t. 19-20, 2006-2007, pp. 13-40.

71 Este hecho podría explicarse, quizá, por causas de índole sociopolítica, ya que, como es sabido, el momento de mayor prosperidad de los etruscos se daba en torno al 530 a.c., cuando poco después de la batalla de Alalía, se convirtieron en los dueños del Mediterráneo, mientras que la caída de Veyes, en el 396 a.C. marcó el comienzo de la decadencia de esta civilización. 
BERNABÉ, A., Textos órficos y filosofía presocrática. Materiales para una comparación, Madrid, 2004

BERNABÉ, A., «Tendencias recientes en el estudio del Orfismo», Ilu. Revista de Ciencia de las Religiones, 1995, pp.23-32.

BIANCHI BANDINELLI, R., Los etruscos y la Italia anterior a Roma, Madrid, 1974

BIANCHI, U., «Misterios de Eleusis. Dionisismo. Orfismo», en Ries J. (ed.), Tratado de antropología de lo sagrado, vol. 3, Madrid, 1997.

BLÁZQUEZ, J. M., «Representaciones de puertas en la pintura arcaica etrusca» en Trabajos de la Escuela Española de Historia y Arqueología en Roma, 9, 1957, pp.49-74.

BLÁZQUEZ MARTÍNEZ, J. M., Imagen y mito: Estudios sobre religiones mediterráneas e ibéricas, Madrid, Ediciones Cristiandad, 1977.

BLOCH, R., The ancient civilization of the Etruscans. New York: Cowles Book, 1969.

BURKE, B., «Materialization of Mycenaean Ideology and the Ayia Triadha Sarcophagus», American Journal of Archaeology, vol.109, n.3, 2005.

$\mathrm{CECl}, \mathrm{F}$., «El banquete y la ceremonia fúnebre» en Príncipes etruscos, entre Oriente y Occidente, Madrid, Ed. Fundación La Caixa, 2008.

CRUM SH./ FOOTE K. E., «An introduction to metaponto and the lago del Lupo» The Geographer's Craft Project, Department of Geography, The University of Colorado at Boulder, 1994. http://www.colorado.edu/geography/gcraft/warmup/meta1/meta1_f.html

CHEVALIER, J., Dizionario dei simboli, Milán, 1986.

DELGADO LINACERO, C., "Símbolo de poder y ofrenda religiosa. El toro en el Mediterráneo Antiguo», Historia 16, n.273, 1999, pp.76-85.

DÍEZ DE VELASCO ABELLÁN, F., Los caminos de la muerte. Religión, rito e iconografía en la Grecia Antigua, en http://www.scribd.com/doc/7383613/Francisco-Diez-de-VelascoLos-Caminos-de-La-Muerte-Religion-Rito-E-Iconografia-en-La-Grecia-Antigua.

DÍEZ DE VELASCO ABELLÁN, F., Historia de las religiones, Tema 13: Muerte y religión, en http://webpages.ull.es/users/fradive/historiacomparada/14muerte/tema14.html.

ELVIRA BARBA, M.A., BLANCO FREIJEIRO, A., Etruria y Roma Republicana, Madrid, 1989.

FERUGLIO, A.E., (e.a.), Pittura etrusca a orvieto. Le tombe di settecamini e degli Hescanas a un secolo dalla scoperta. Documenti e materiali, Roma, Edizioni Kappa, 1982.

FRANCHI, L., «Rilievo con pompa funebree rilievo con gladiatoria al Museo dell Aquila» en VV.AA., Sculture romana nell area sabelica, Studi Miscellanei, 10, Roma, 1966.

GONZÁLEZ SERRANO, P., «Animales míticos en el mundo clásico», Espacio, Tiempo y Forma, Serie II, Historia Antigua, t. 11, 1998

GONZÁLEZ SERRANO, P., "Catábasis y Resurrección», Espacio, Tiempo y Forma, Serie II, t. 12, 1999.

GONZÁLEZ SERRANO, P., «Las estelas del adiós», en Más cerca de Grecia, ㄲo 5, 1990, págs. 89-94.

HERRERO DE JÁUREGUI, M., Tradición órfica y cristianismo antiguo. Supervivencia postmortem e identidad personal en el orfismo, 2007.

LONG, C., The Ayia Triadha Sarcophagus, A study of Late Minoan and Mycenaean Funerary Practices and Beliefs, Goteborg, 1974.

MARTÍNEZ PINNA, J., «In convivio luxuque: mujer, moralidad y sociedad en el mundo etrusco», en Brocar: Cuadernos de Investigación Histórica, 20, 1996.

MATHIESEN, TH. J., Apollo's Lyre: Greek Music and Music Theory in Antiquity and the Middle Ages, Lincoln, University of Nebraska Press, 1999.

MOLINA MORENO, F., «Quinteto para dioses músicos en la mitología griega», Estudios clásicos, Tomo 40, № 113, 1998, pp. 7-36.

MONTERO HERRERO, S., «Astrología y «Etrusca disciplina»: contactos y rivalidad», en MHNH: revista internacional de investigación sobre magia y astrología antiguas, n. 1, 2001, pp. 239-260. 
NILSSON, M. P., The Minoan and Mycenaean Religión and its survival in Greek Religión, Lund, 1950.

OGDON, J.R., «Estudios sobre la magia egipcia antigua, II. Probables arquetipos para la bruja (occidental) clásica», en Asociación Española de Amigos de la Egiptologia. Sección de Religión y Mitología. Publicado en 2005.

PENNY SMALL, J., «Eat, Drink and be Merry: Etruscan banquets», en VV.AA., Murlo and the Etruscans. Art and Society in ancient Etruria, University Wisconsin Press, 1994.

RODRÍGUEZ LÓPEZ, M.I., Mar y Mitología en las culturas mediterráneas, Madrid, 1999.

RODRÍGUEZ LÓPEZ, M. I., «El arte cicládico», en E-Excellence. http://www.liceus.com, 2005. (21 pp.). ISBN: 84-9822-112-9.

RODRÍGUEZ LÓPEZ, M.I., "La música de las sirenas», Cuadernos de Arte e Iconografía, Fundación Universitaria española, Tomo XVI, n.32, 2007.

SIAN PECK, M., «Dining with Death: An Análisis of Attic White-ground Lekythoi and Atenían Notions of Afterlife in Classical Greece, The Joukowsky Institute (Brown University), on line: http://brown.edu/Departments/Joukowsky_Institute/undergrad/prizes/Peck2007.pdf.

VV.AA., Dictionary of Greek and Roman Antiquities, John Murray, Londres, 1875.

\section{OTRAS REFERENCIAS ON LINE}

Baccolini, G., «La tomba dei Leopardi» en http://www2.fci.unibo.it/ baccolin/tomba\%20leopardi/La\%20tomba\%20dei\%20Leopardi.htm

DÍEZ DE VELASCO ABELLÁN, F., Historia de las religiones, Tema 13: Muerte y religión, en http://webpages.ull.es/users/fradive/historiacomparada/14muerte/tema14.html

«Le Tombe etrusche di Tarquinia», http://www.canino.info/inserti/monografie/etruschi/tombe_tarquinia/

MOSCATELLI, G., L'Eros degli Etruschi, Alle origine dell erotismo mediterraneo, en http://www.canino.info/inserti/monografie/etruschi/eros_etruschi/eros_etruschi_4.htm

The Dance: Historic Illustrations of Dancing from 3300 B.C. to 1911. Project Gutenberg .http://www.archive.org/details/thedancebyananti17289gut

«The Dancers-Professional bureau, Foreign dancers, Dancing dwarfs, Pygmies, A prince sends the khener to a funeral, Story of a khener», http://encyclopedia.jrank.org/articles/pages/50/The-Dancers.html 
